\title{
Lava rotary querns of 'Iron Age type’ in Roman times
}

\author{
Stefan Wenzel
}

KB Vulkanologie, Archäologie und Technikgeschichte, Römisch-Germanisches Zentralmuseum, An den Mühlsteinen 7, 56727 Mayen, Germany. Email: wenzel@rgzm.de

\begin{abstract}
:
In Mayen the production of lava rotary querns of 'Iron Age type' continued from the late La Tène period into Julio-Claudian times. The lower quernstone possessed a domed grinding face and the upper stone was double concave in section. While the surfaces of these querns are usually pecked, late examples show a segmented radial grooving on the grinding surfaces. Handle sockets with elbowshaped (L-shaped) perforation were already an innovation of the late Iron Age.

Since Augustan times ‘typical Roman’ hand-mills were the main product of the Mayen quarries. They had a meta with a flat conical grinding surface and a catillus with a broad raised rim. The active surfaces were grooved for functional reasons. However, the upper side of the catillus and the sides of upper and lower stones were grooved for decoration, making these rotary querns a characteristic 'branded' product.

Most of the 'Iron Age type' quernstones of Early Imperial times are known from the Low Countries where they go under the name of Brillerij-type. A survey of these quernstones reveals several examples found to the southeast of this region. Even after the typical Roman hand mills became the dominant form, some 'vintage' Iron Age type querns were still produced for a special clientele. Though, so far, virtually no closely dated specimens are known from contexts after the Batavian revolt.
\end{abstract}

Keywords: rotary quern; Iron Age; La Tène culture; Roman period; Brillerij-type

\section{Introduction}

Between Mayen and Mendig, close to the Rhine, Mosel and Lahn, lies one of the largest ancient quarrying areas north of the Alps for the extraction of saddle querns and millstones from “basalt”-like lava (Hörter et al. 1951; Mangartz 2008; Wefers 2012a; Wefers \& Gluhak 2010). Already for the saddle querns of the late Hallstatt Period (Joachim 1985: 360) as well as for the Iron Age rotary querns, which were found as far as present-day Hesse (Wefers 2012a: 167), the find distribution suggests that these products were transported on waterways to customers outside the region. Also, in later times fluvial transport remained crucial (Enzmann 2016).

From the early Roman period, quarrying further increased and exports expanded (Mangartz 2008: 52, 93-101; Schaaff 2010: 268). The opening of new quarries (Mangartz 2012: 2) and the establishment of new settlements continued not only a trend already

Published by the School of History, Classics and Archaeology, University of Edinburgh ISSN: 2055-0472. URL: http://journals.ed.ac.uk/lithicstudies/ 
discernible for the Late Iron Age (Oesterwind \& Wenzel 2012: 352), but got a new quality. There are indications of a division of labour in the production of millstones, with a spatial separation of production steps, and a firmly organized transport (Mangartz 2012: 9-10, 1719). Probably the state intervened: the quarry area of Mayen was newly parceled out (Hörter et al. 1955: 12-14; Mangartz 2008: 91-92; 2012: 14-15) and the settlement was transferred in the valley to the Nette (Oesterwind 2000: 37-38). Mayen became a town, with paved streets, a water pipe system, thermae, separated quarters of potters and stonemasons, and - perhaps later - a temple (Giljohann et al. 2017: 130; Glauben 2012: 88-91; Hunold 2002: 73-82). Since Augustan times the military has been a buyer of novel products: "Type Haltern” querns, whose runners have a locating tab, and millstones of the types "Haltern - Rheingönheim" and "Pompeii" (Baatz 1995; 2015; MacKie 2007: 493).

The querns manufactured since the early imperial period in the vicus of Mayen and in villae near the quarries (e.g., Wenzel 2012: 135, fig. 6) usually have a standardized shape and surface modification (Green 2017: 174; Mangartz 2008: 73, 82-83): the runner (catillus) and the lower stone (meta) have a cylindrical basic shape, with a diameter of approximately 35-40 cm (Figure 1:1-4). The upper stone has a broad $(4-5 \mathrm{~cm})$ and distinctly stepped rim, its underside is adapted to the lower stone with its flat conical grinding surface. The upper stones usually have an 'elbow-shaped' perforation for the handle, "with a broad hole in the outer surface leading through to a slightly smaller hole in the upper surface” (Hill et al. 2011: 351). The underside of the lower stone is hollowed out to reduce the weight. Grooves carved in the grinding surfaces increased the effectiveness of the mills. In addition, grooves were chiselled on top of the runners and on the side surfaces of runners and lower stones for decoration.
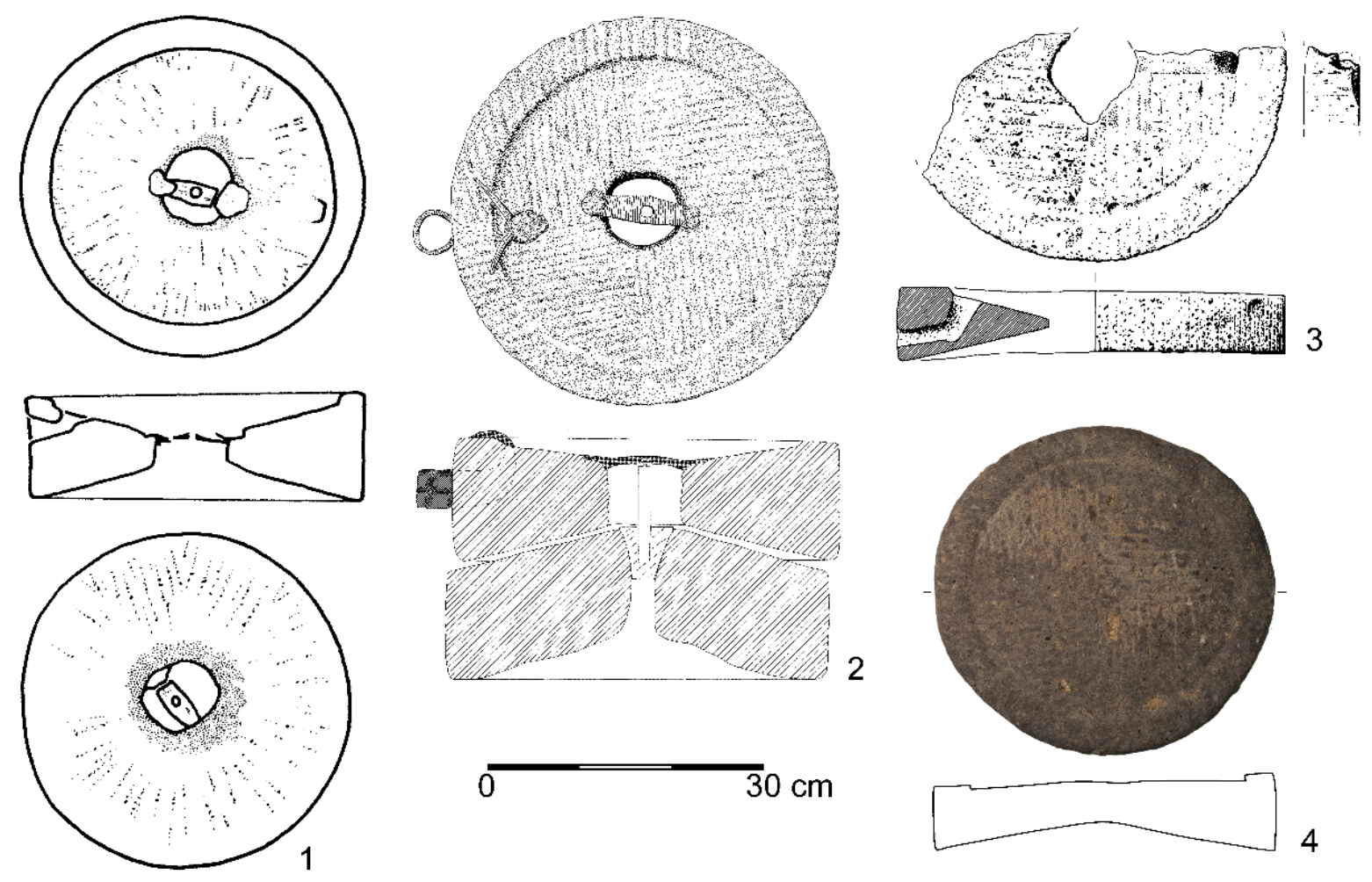

Figure 1. Upper stones of ‘typical roman’ querns (1.3), a pair of quernstones (2) and a roughout (4), dating from the first century CE. Provenances: 1. Waldgirmes; 2. Newstead; 3. London, Leadenhall Court; 4. Mendig, "Im Winkel”. (1 Baatz 2015: fig. 246; 2. McKie 2007: fig. 10, 56; 3. Milne \& Wardle 1996: fig. 46, 75; 4.) (Photo B. Streubel) 
The decoration of the quernstones with grooves is considered typical of the products of the Bellerberg volcano at Mayen, which gave them the appearance of a "branded article" (Mangartz 2008: 82). As it is usual with branded products, they were imitated (Rees 2011: 111; Shaffrey 2010: 877; 2011: 372). A find in the wreck "De Meern 1" shows that the typical "legionary quern" remained in use at least until the second half of the 2nd century, if not until the first decades of the 3rd century (Jansma et al. 2014: 495; Mangartz 2007;). Blanks for hand mills were rarely exported, which then could get a form deviating from the standard (Baatz 2015: 300, fig. 248; Hörter 1994: 31).

In contrast to the 'typical roman' querns, a quern from a grave in Ettringen near Mayen is of interest, which belongs to the 3rd quarter of the 1st century CE (Figure 2) (List of findspots with references as supplementary material ("List"), 24). It shows a combination of features known from Iron Age querns with those found at Roman hand mills. Again, both stones roughly have a cylindrical shape. The domed grinding surface of the meta and the biconcave cross-section of the catillus are common features of Iron Age querns, as well as the picked outer surfaces. The sharpening of grinding surfaces with grooves however is considered characteristic of Roman millstones and is rather rare on pre-Roman specimens (Wefers 2012a: 75-78). Obviously, standardization was not taken too seriously here and the production of an old quern type had been continued.

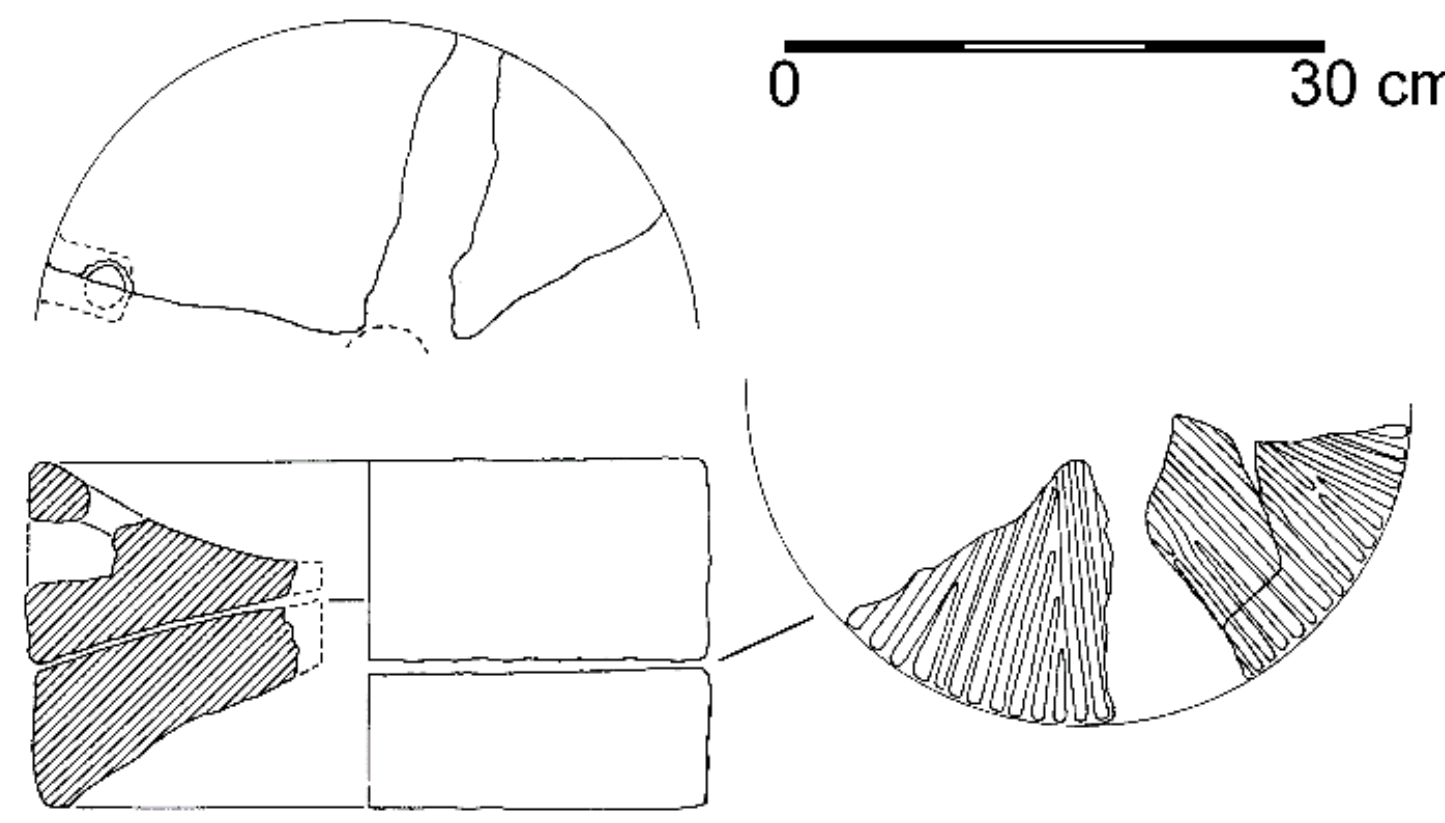

Figure 2. A pair of quernstones from Ettringen. "Basalt”-like lava. (Oesterwind 1997: fig. 6).

\section{Background}

Querns similar to that of Ettringen have been described by Otto Harm Harsema (1967: 141) as "type Brillerij"; he specified the differences to classic Roman handmills which he called "type Westerwijtwerd". He published several examples from the Netherlands (Figure 3: 1-2), including one excavated at Rasquert from a context of the 1st century CE (Harsema 1967: 145, fig. 5:3) and referred to mineralogical analyses, which throughout named Mayen as origin of the raw material (Harsema 1967: 151). Harsema (1967: 150) also noted that the Brillerij type is not present in the article by Fridolin Hörter et al. (1951), who summarized the knowledge at that time of the Mayen quarries and their products. This suggests that quernstones of the Brillerij type were not known in great quantities in their area of origin (see 
also: Crawford \& Röder 1955). A new survey of Brillerij type quernstones in connection with the description of an upper stone from Tongeren (Figure 3:3) mentions the quarries at Mayen as the origin of the material of some of the specimens, but only includes pieces from the Netherlands and Belgium (Hartoch et al. 2015: 178).
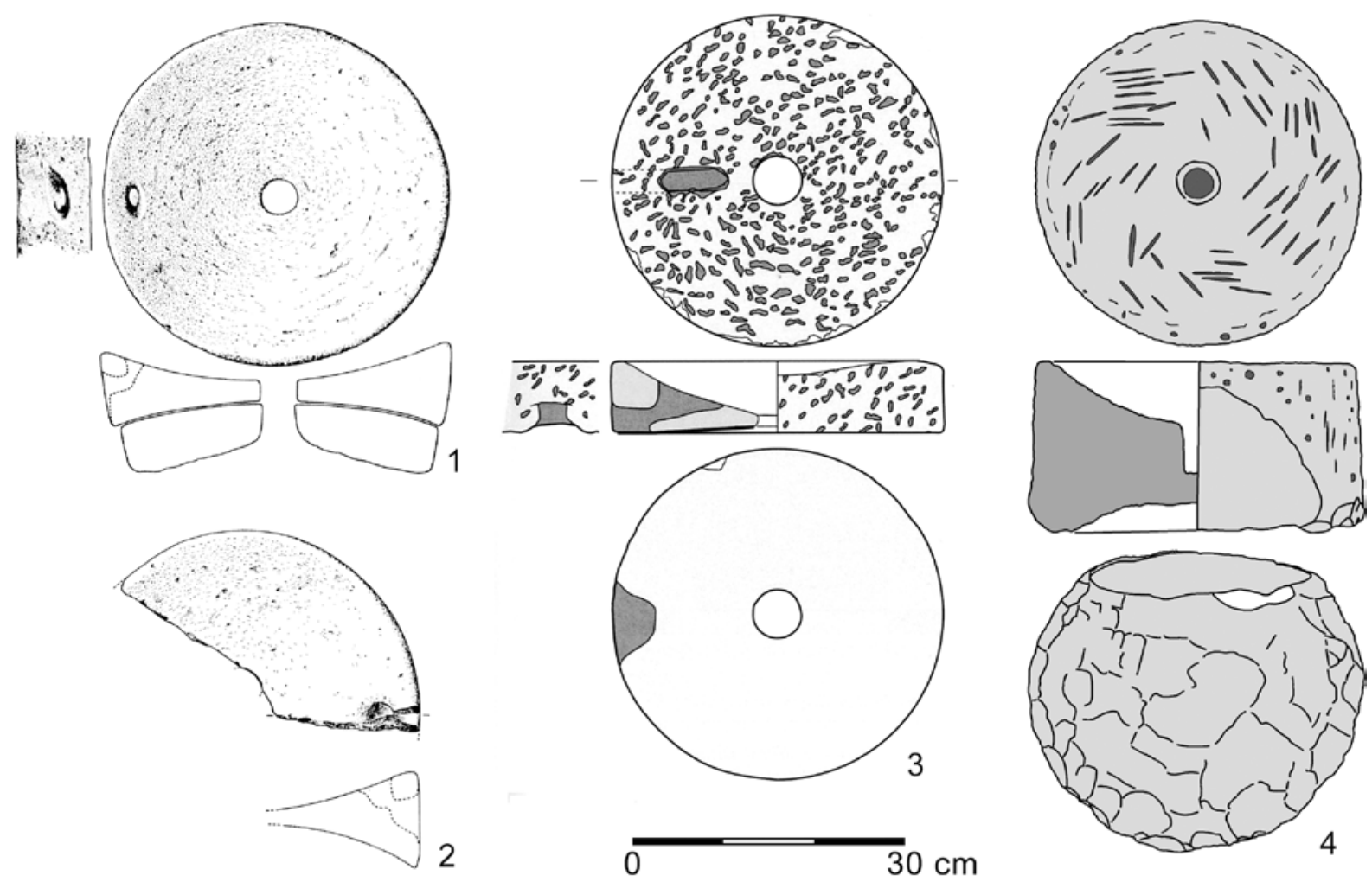

Figure 3. Quernstones of Brillerij type. 1: upper and lower stone, 2-3: upper stones, 4: roughout for upper stone. Provenances: 1. Brillerij; 2. Rasquert; 3. Tongeren, Bilzersteenweg; 4. Mayen or environs. (1-2. Harsema 1967: fig. 5:1-1a.3; 3. Hartoch et al. 2015: fig. 121).

Similar querns with runners of a bi-concave cross section have been called "celtic" querns or "La Tène querns" (Hörter 1994: 22; Mangartz 2012: fig. 6:1). These querns may be regarded as a variant of the Brillerij type querns, though they differ in two details: The hole for the handle in the runners is horizontal, not elbow-shaped, and the underside of the lower stones is not hollowed out. Although querns with runners of bi-concave cross section were particularly common in the Late Iron Age and were produced from various materials (e.g., Wefers 2012a: Pl. 62:362, 70:439, 107:570), there was a great diversity in the design of the lower stones as well as of the edges and eyes of the runners (Wefers 2006: 68, fig. 3-4; Peacock 2013: fig. 4.4; Lepareux-Couturier et al. 2017: fig. 15). To describe the querns which are the subject of this article, the term "type Brillerij" therefore seems most appropriate. Usually also lower stones found separately are assigned to this type (Harsema 1967: 157 no. 8-9, fig. 9:8-9; Hartoch et al. 2015: 278; Van Heeringen 1985: 379 DR 1;). This is also practised here, although lower stones cannot be attributed to the Brillerij type with the same certainty as runners, because in some cases they may have belonged to runners with stepped rim (e.g., Baatz 2015: fig. 248; Engels 1976: Pl. 30:9; Hartoch et al. 2015, Cat. ํ 50-51; Stümpel 1991: fig. 5; Wefers 2012a: Pl. 53:278;). Isolated lower stones are therefore mapped with open symbols.

In this paper the term "lava" or "Mayen lava" is used for the "basalt"-like lava of the Bellerberg volcano (according to Reniere et al. 2016: 410), which is scientifically named phonotephrite (Gluhak \& Hofmeister 2009: 1777). The terms leucite-nepheline tephrite to 
tephritic foidite (Kars 1983: 119) or nepheline-tephrite (Williams \& Peacock 2011: 453) have also been used. It has been possible to assign the material of archaeological finds of quernstones and millstones to particular lava flows of the Bellerberg (Gluhak 2010; Gluhak \& Hofmeister 2011: 1610; Gluhak \& Wefers 2011: 80).

In all three lava flows of Mayener Bellerberg, the production of millstones of Iron Age design is also testified by blanks and failed specimens (Lung 1962: Pl. 17:3; Mangartz 2008: 258 no. 1-70.1, fig. 177, 49-53.231.271-273, Pl. 17). From the quarry district of Mayen originates probably a failed half-finished catillus (Figure 3:4), which came to the Museum Mayen before 1914 (see Supplementary List, 44). It had been discarded after a big flake had been broken off from the side.

\section{Methodology}

References to relevant quernstones were collected from literature. Images were converted to the scale 1:5 (here reproduced in scale 1:10) to be used for making visual comparisons. Own drawings are based on suggestions of the Groupe Meule (Jaccottey \& Farget 2011). Maps were produced using QGIS 2.4 Chugiak. For the translation of technical terms, the "Dictionary of Molinology" by Yves Coutant et al. (2004) and the essay by Will Wootton et al. (2013) have been consulted.

\section{Quernstones of Brillerij type and their context}

\subsection{Quernstones of Brillerij type from Iron Age contexts}

Particularly early rotary quernstones are known from Els Vilars (525-500 BCE) and Alorda Park (500-400 BCE) in the region of Catalonia in northeastern Spain (Alonso Martínez \& Pérez Jordà 2014: 245). Therefore, rotary querns may be an Iberian (Alonso Martínez \& Pérez Jordà 2014: 239) or Phoenician invention (Wefers 2011: 69). Since it was possible to process grain to flour six to twelve times more effectively with a rotary quern than with a saddle quern (Holodňák 2001: 44; Wefers 2011: 67), this innovation was soon adopted north of the Pyrenees (Jaccottey et al. 2013).

Around 250 BCE this practical invention arrived in the area of the Mayen millstone quarries (Wefers 2011: 73 note 7). In pit 5 of the settlement of Kottenheim, "Im Hengst" the roughout of a meta with slightly domed working face was found (Figure 4:2), together with fragments of a saddle quern (Holtmeyer-Wild 2000: 55, pl. 17:11), ceramics and bones of cattle and pigs (Haberey \& Rest 1941; Lung 1962: 45-46; Bockius 1992: 263 no. 94). Pit 3 from ca. 150 BCE contained the roughout of a smaller meta with domed top side (Figure 4:1).

The export of Brillerij type querns started early. From the settlement MD 15.04 at Maasland, Foppenpolder (the Netherlands) from circa 200 BCE originate fragments of a saddle quern in form of a Napoleon's hat and fragments of a rotary quern of the Brillerij type, both of lava from the Eifel (see Supplementary List, 42).

According to a ${ }^{14} \mathrm{C}$ date and to the weapons found there, the settlement of EschweilerLohn, near Aachen (see Supplementary List, 23), was mainly inhabited between 200 and 150 BCE. There, a lower stone of a rotary quern with convex working face was found (Figure 5:5) as well as flat saddle querns of basalt lava and red sandstone (Joachim 1980: 400.402, fig. 27:3). The nearby settlement of Eschweiler-Laurenzberg with its numerous fragments of Brillerij type quernstones of basalt lava (Figure 5:1-4) (List, 22) is probably a bit younger than Eschweiler-Lohn and dates mainly to circa 125-80 BCE (Joachim 1980: 371; Lenz 1995: 160-161; Lenz \& Schuler 1998: 595). 


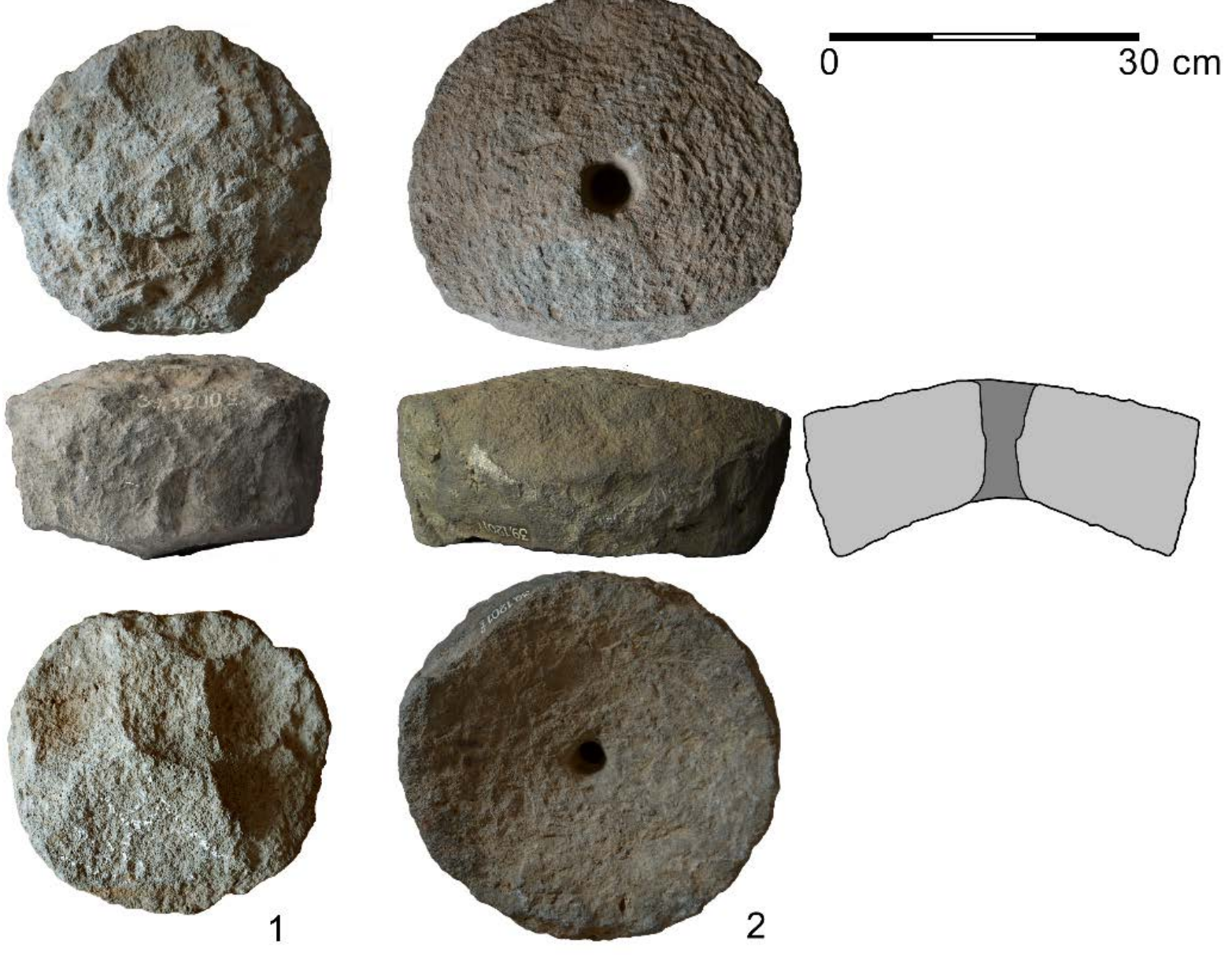

Figure 4. Roughouts for lower stones, probably of Brillerij type, from Kottenheim, "Im Hengst“ (1 pit 3; 2 pit 5). "Basalt"-like lava.

Both, the lower stones as well as the runners of the rotary querns found at EschweilerLaurenzberg, have distinctly domed or concave grinding surfaces. In this settlement saddle querns were also still in use (Joachim 1980: 434.438). Bowls with carinated shoulder and profiled or canted lips indicate Germanic inhabitants of the settlement (Lenz 1995: 160), as well as the presence of an unusual cereal spectrum, which "with its primacy of barley has a close connection with the barley-oat-emmer region of the North German lowlands" (Lenz 1995: 161, translated), or with North Holland (Knörzer in Joachim 1980: 454). The husked barley was well storable and may mark the beginning of a 'tradable overproduction' (Kalis \& Meurers-Balke 2007: 147), if it was not used as malting barley (Kreuz \& Baatz 2003: 22; Shaffrey 2015: 70-72). It is quite possible that the querns were adapted for the processing of this peculiar grain, if not for the crushing of malt.

Fragments of Brillerij type upper stones made of lava were found in the fortified settlement of Niederzier-Hambach (Hambach 382) (Figure 5:7; List, 50), which existed from late La Tène C2 to La Tène D2a (c. 160-55 BCE) (Joachim 2009: 42). Saddle querns made of sandstone were still in use in this village (Joachim 2009: Pl. 21:12). Here, too, bowls with canted lips (e.g., Joachim 2009: Pl. 20:8) are indicative of Germanic inhabitants, perhaps Eburones (Joachim 2006: 448), which may have been among the Germani cisrhenani as named by Caesar (BG II, 3). 

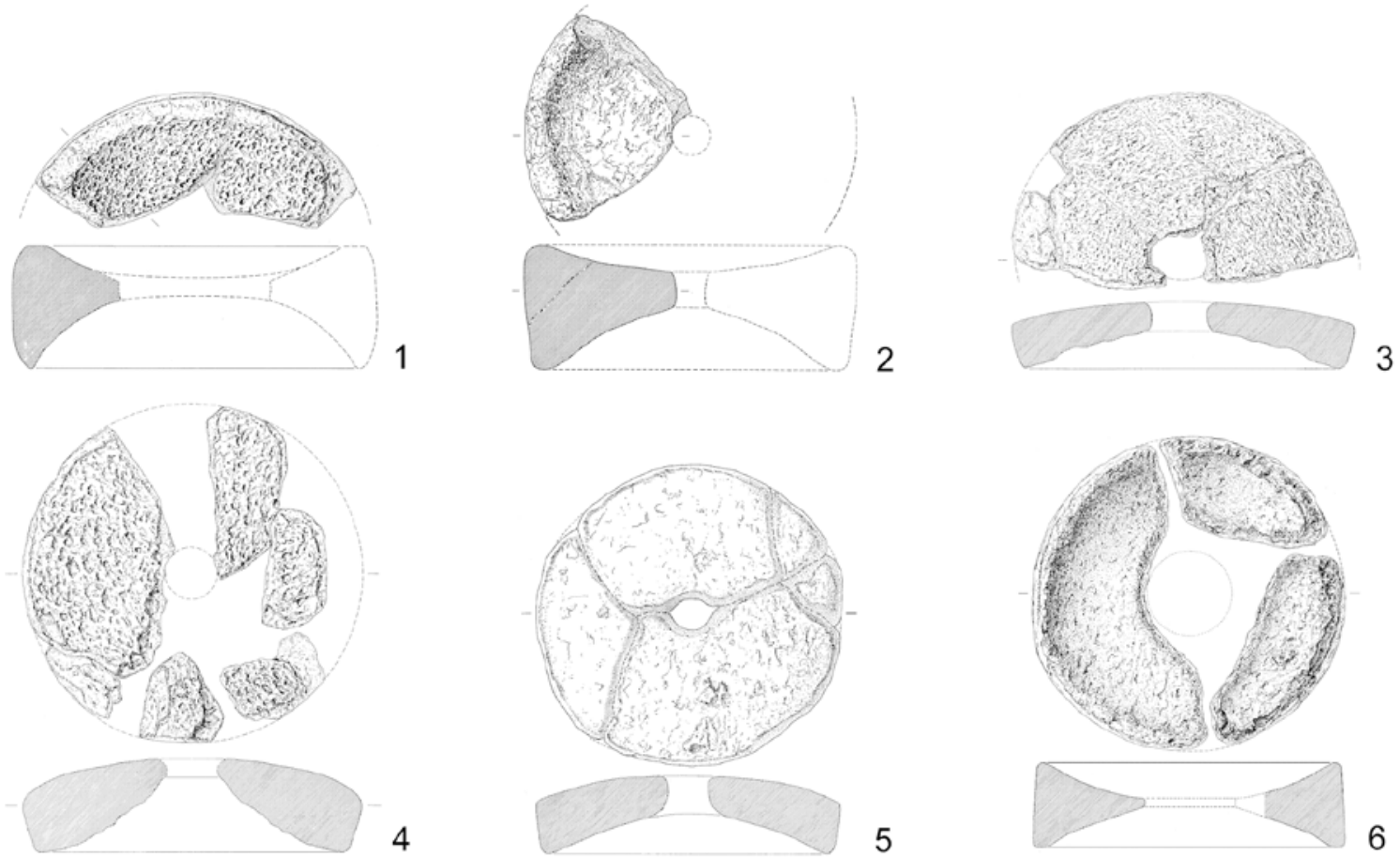

4

5
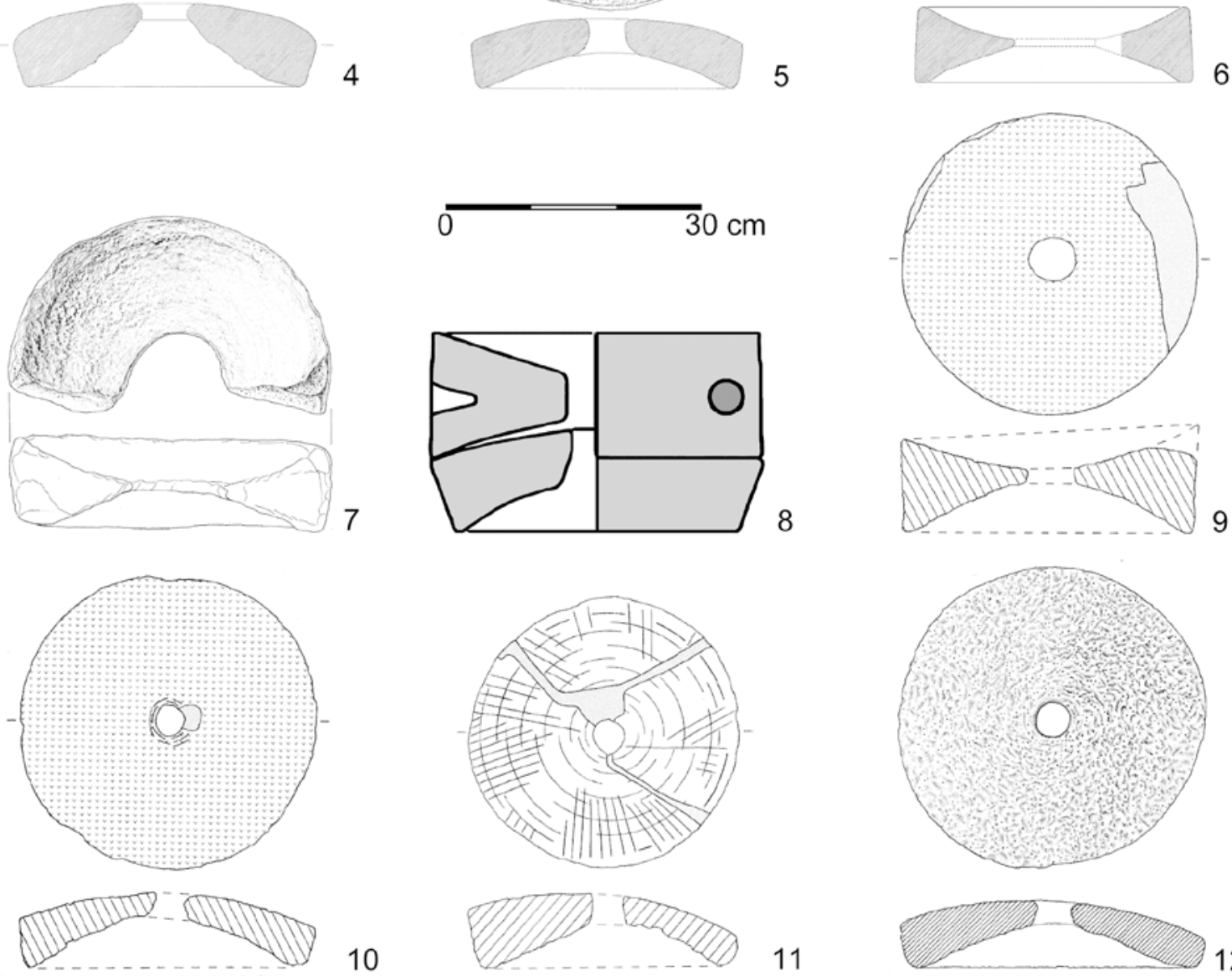

10

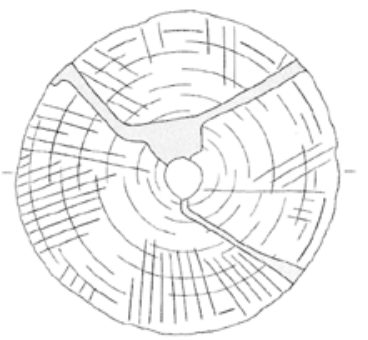

11

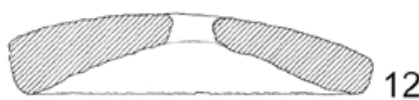

Figure 5. Iron Age quernstones of Brillerij type. 1-2,6,7, 9: upper stones; 3-5,10-12: lower stones; 8: lower and upper stone. Provenances: 1-4. Eschweiler-Laurenzberg; 5. Eschweiler-Lohn; 6. Petersberg near Königswinter; 7. Niederzier-Hambach; 8. oppidum "Fosse des Pandours" near Saverne; 9-10. Bad Nauheim; 11. oppidum Dünsberg near Biebertal-Fellinghausen; 12. oppdidum Trînchy near Cugnon. All "basalt”-like lava. (1-5. Joachim 1980: fig. 25:2, 27:4, 16:4, 17:4, 46:5; 6. Joachim 1982a: fig. 15:3; 7. Joachim 2009: Pl. $20: 11 ; 8$. Jodry \& Féliu 2009: fig. 5; 9-11. Wefers 2012a: pl. 10:47, 11:49; 12. Matthys \& Hossey 1979: fig. 14:5).

While the previously mentioned upper stones do not permit any statements to how the handle was attached to them, a fragment of a catillus of the Brillerij type made of lava (Figure 
6:10) from well 12.30 of Oss-Brabantstraat in the Netherlands (List, 55) shows an elbowshaped hole for the handle. The well is dated based on pottery to 185-125 BCE (de Leeuwe 2001: 89) and contained also a runner of a saddle quern made of lava (Knippenberg 2001: 98, fig. 62).
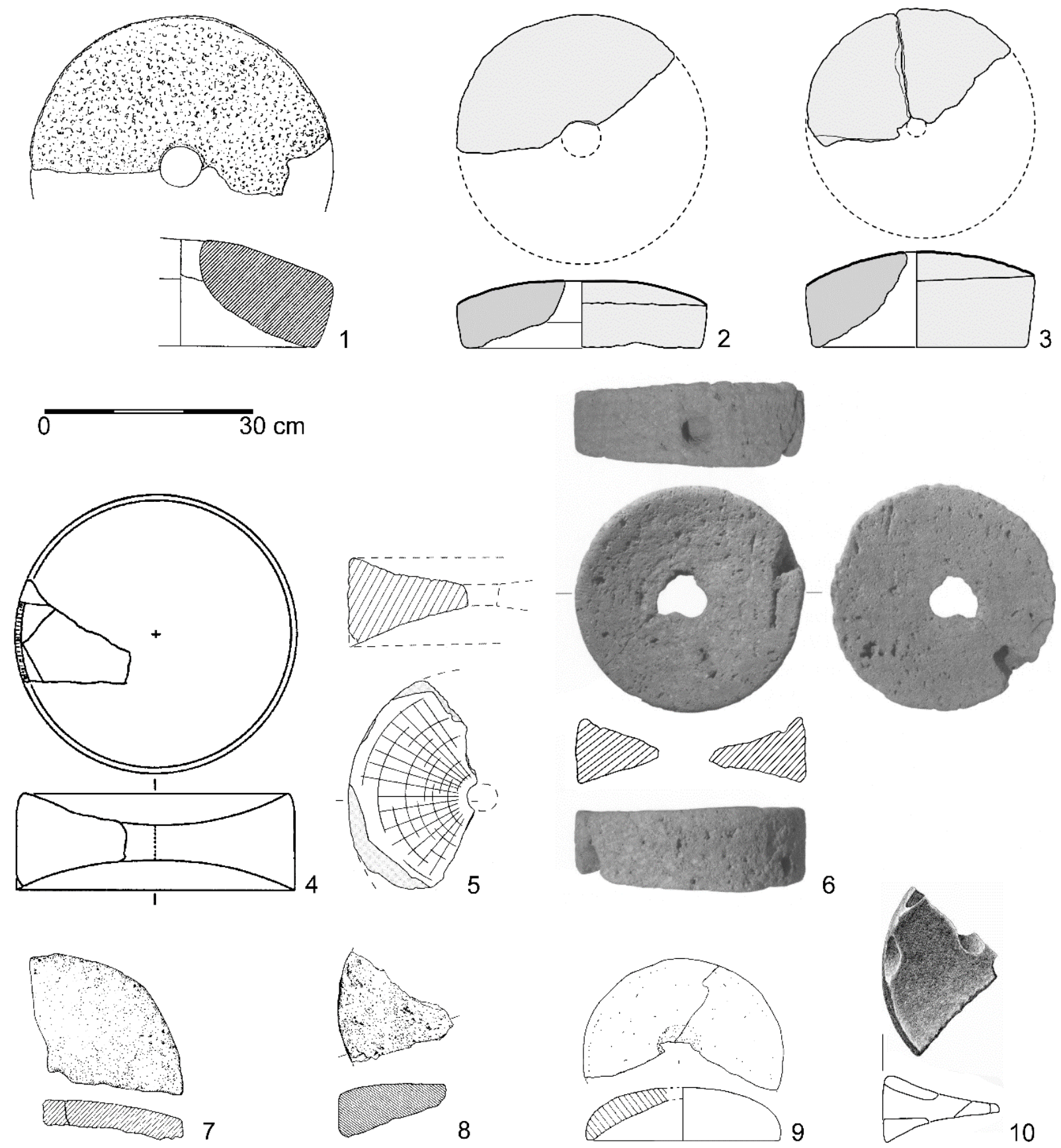

Figure 6. Iron Age quernstones of Brillerij type. 1-3, 7-9: lower stones; 4-6, 10: upper stones. Provenances: 1. Saffig, "Im Weidenfeld”; 2-3. Dannenfels, oppidum Donnersberg; 4. Heidetränk-Oppidum; 5. Hommertshausen, "Eisenköpfe"; 6. Geldermalsen-Hondsgement; 7. Sünninghausen, 8. Oss-Ussen, Westerveld, 9. Creil; 10. Oss, Brabantstraat. All volcanic rock. (1. Hörter 2000: fig. 2:5; 4 Staubitz 2007: pl. 1:1; 5. Wefers 2012a: pl. 41:216; 6. van Pruissen \& Kars 2009: fig. 10.9; 7. Wilhelmi 1973: pl. 11:246; 8. Schinkel 1998: fig. $127 b ; 9$. Fémolant 1989: fig. 28:1; 10. Knippenberg 2001: Fig. 61).

Finds from pit 3 in the oppidum "Fosse des Pandours" near Saverne in France (List, 65) show that circa 120 BCE two alternatives for the attachment of handles to the upper stones were known (Jodry \& Féliu 2009: 70). The pit contained two pairs of quernstones with 
diameters between 36 and $39 \mathrm{~cm}$, whose material is given as "basalte". One of them corresponds to the type Brillerij (Figure 5:8). The runner has a horizontal cavity with a round cross-section into which the wooden handle originally was driven.

At the salt production site of Bad Nauheim (Germany), "Lattkaute" Brillerij type quernstones of Eifel lava (Figure 5:9-10) have been found (Wefers 2012a: 111). The site belonged to a spacious area of salines, which was in use from circa 250 BCE until the turn of eras (Hansen 2016: 99). However, few pieces of wood have been found at "Auf der Lattkaute”, dating dendrochronologically to Domitianic times (Hansen 2016: 91). In the La Tène period crafts practised in the saltworks area included wood working, ceramic production, forging iron, casting bronze and working amber (Hansen 2016: 94-95); there were also millstone quarries in close proximity (Wefers 2012a: 110.155). The pottery from Bad Nauheim shows Celtic and Germanic influences (Hansen 2016: 99).

In the nearby Heidetränk oppidum (List, 53) 88 of 171 studied quernstones are made of Eifel lava (Wefers 2012a: 119, fig. 53), and among those are several Brillerij type examples (e.g., Wefers 2012a: Pl. 52:252.257; 56:302-303, 57:316, 59:335, 65:414) (Figure 6:4). Possible explanations for the high portion of quernstones from this source are the supposed economic power of the residents and the early end of the settlement before 80 BCE (Wefers 2012a: 179). Lower stones, which may have belonged to Brillerij type querns, come from the oppida of Dünsberg in Germany (Figure 5:11; List, 8) and Trînchi near Cugnon in Belgium (Figure 5:12; List, 15). In the oppidum Donnersberg near Dannenfels, a Brillerij type catillus was found (Zeeb-Lanz 2008: fig. 49 right), as well as upper stones of other types (Engels 1976: 40, pl. 30:9; Zeeb-Lanz 2008: fig. 49 left) and several lower stones (Figure 6:2-3), all made from "basalt"-like lava.

Findspots on hillforts are the Petersberg near Königswinter (Figure 5:6; List, 38), the Dornburg near Dornburg-Wilsenroth (List, 20), "Eisenköpfe” near Hommertshausen (Figure 6:5; List, 33) and "Kleines Steinchen” near Daaden (List, 16), all in Germany. From Iron Age settlements, a catillus from Geldermalsen-Hondsgement, Netherlands (Figure 6:6; List, 25) and lower stones from Oss-Ussen, Westerveld, the Netherlands (Figure 6:8; List, 57), and from Saffig (Figure 6:1; List, 64) and Oelde-Sünninghausen in Germany (Figure 6:7; List, 54) are reported. Several fragments of upper stones have been found in the ditch around the settlement of Zeijen-Witteveen in the Netherlands (List, 75).

The material of a meta from Creil (Oise, France; Figure 6:9; List, 14) is described as vesicular basalt, with the only known outcrop is at Maar in the district of Daun in the Eifel (now Vulkaneifel district) close to the Rhine (Fémolant 1989: 62). This probably is a misunderstanding: There are several volcanic rock deposits in the environs of Daun (Hörter 1994: 107 no. 45, nos. 49, 53, 59, 88, 93; Mangartz 2008: fig. 46), which were used for quernstones and millstones, but only for local demands, because they are situated far away from the Rhine. If the raw material of this unusual small lower stone originates from the Eifel at all, Mayen would be the more likely source. Creil is situated near the mouth of the river Le Thérain into the Oise, at the crossroads of fluvial and terrestrial routes, near a ford and a harbour (Fémolant 1989: 43-44).

Already during the Gallic War, the Roman army began to use rotary querns of lava from Kottenheim near Mayen. The fragment of a Brillerij type runner was discovered in a military camp near Hermeskeil in Germany (List, 32), where quernstones of various shapes and materials document the troop's previous path (Hornung et al. 2015; Hornung 2016: 152, fig. 130:1). To the aftermath of the Gallic War dates a pair of broken Brillerij type quernstones from grave 1/2013 of the cemetery of Bierfeld, "Vor dem Erker" near Nonnweiler, Germany (Gleser \& Fritsch 2015: 162, fig. 12.18). 


\subsection{Quernstones of the Brillerij type from Roman contexts}

Several Brillerij type quernstones have been found in Roman military camps of the Augustan period in Germany: in Barkhausen (Figure 7:1; List, 6) and Rödgen (Figure 7:2; List, 62) fragments of runners; in Hedemünden, a lower stone (Figure 7:4; List, 31), which was obviously not used in its original function (Wefers 2012b). Secondarily modified was also a half catillus from the oppidum Martberg near Pommern and Karden (Figure 7:5; List, 59), which had been disposed of in a pit of the Oberaden and Haltern horizons (Nickel 2011: 105.255, fig. 45). Its working face has two generations of grooves: very thin and long grooves that look almost fresh, as well as wide and short elongated depressions with rounded edges. On the side face are two horizontal holes for handles. Two holes, placed on the upper surface on both sides of the eye, which was no more centric at the end, belong to a phase of secondary use.

Fragments of Brillerij type querns dating to Augustan times were also found in the context of a supposed watermill at Inden-Altdorf in Germany (List, 36). The runner has apparently an elbow-shaped perforation for the handle (Figure 7:3). The pottery from this place, e.g., vessels with cube-shaped profiles of the lips, indicates Germanic operators of the plant (Geilenbrügge \& Schürmann 2010: 64, fig. 71).

To the first half of the first century belongs a fragment of a Brillerij type quernstone, which was recovered in the occupation floor of a building in rue Paille-Maille, just outside of Roman Metz, in France (Figure 7:9; List, 46). It is made of lava from the Eastern Eifel or the Chaîne des Puys in the Auvergne, and was secondarily converted into a kind of grinding stone or mortar until its base broke through (Asselin et al. 2017). In the settlement area LR42 of the excavation Utrecht, Sportpark Terweide (the Netherlands), both Brillerij type querns (Figure 7:8-9) and classic Roman hand mills of type Westerwijtwerd have been found. The settlement dates to 20-60 CE, but most of the 'lithic finds' come from a crevasse layer with organic material from 5-9 or 23-127 cal. CE (den Hartog 2009, 22; Mooren 2009: 124, fig. 6:254.255; Taayke et al. 2012: 210 note 369).

In the cemetery "Briedeler Heck" near Briedel, Germany (List, 11), spot 4 in tumulus A 9 of the barrow cemetery A, contained the fragment of a Brillerij type upper stone of "basalt"like lava (Figure 8:3), dating to around the middle of the first century or from Claudian to Vespasianic times. In tumulus 3 of the barrow cemetery B, the fragment of a lower stone from the time of Claudius (Figure 8:4) was detected.

Outside the Neronian legionary camp Vetera I near Xanten-Birten (Germany), a fragment of a catillus made of lava (Figure 8:2) was found in the planum of a pit (List, 74). It has no broad rim and falls in the variation range of the type Brillerij. Apparently, the pit was associated with the camp of the legio V alaudae and the legio XV Primigenia, which was built around $60 \mathrm{CE}$ and whose suburb was demolished in $69 \mathrm{CE}$ by the Romans due to the threat of the Batavi. After the revolt of the Batavi, the camp was moved about $1 \mathrm{~km}$ to Vetera II in 70 CE (Gechter 1987: 620-625).

Outside the Neronian legionary camp Vetera I near Xanten-Birten (Germany), a fragment of a catillus made of lava (Figure 8:2) was found in the planum of a pit (List, 74). It has no broad rim and falls in the variation range of the type Brillerij. Apparently, the pit was associated with the camp of the legio V alaudae and the legio XV Primigenia, which was built around $60 \mathrm{CE}$ and whose suburb was demolished in $69 \mathrm{CE}$ by the Romans due to the threat of the Batavi. After the revolt of the Batavi, the camp was moved about $1 \mathrm{~km}$ to Vetera II in 70 CE (Gechter 1987: 620-625). 


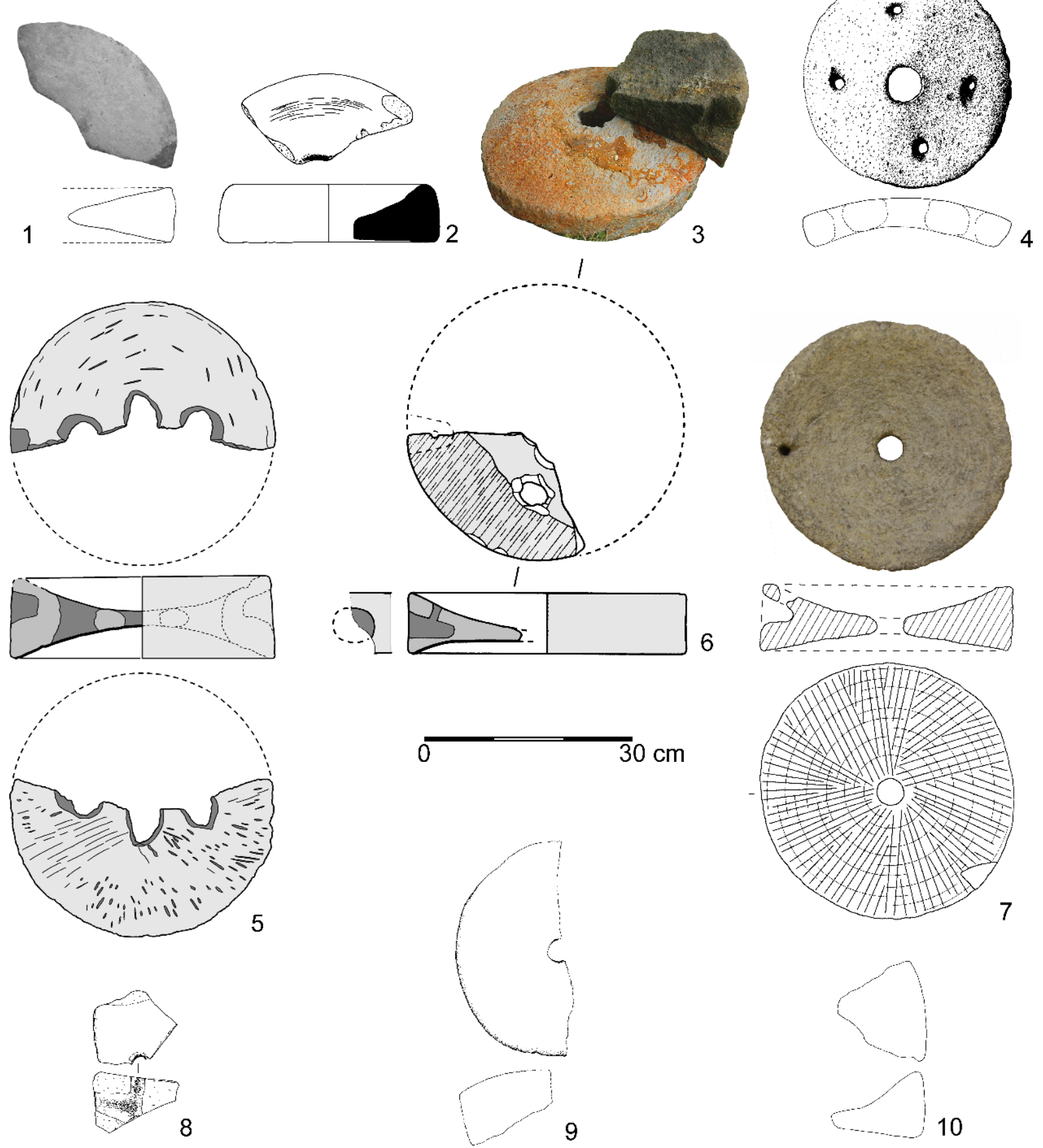

Figure 7. Quernstones of Brillerij type from Roman times. 1-2,5-8,10: upper stones; 3: upper and lower stone; 4,9: lower stones. Provenances: 1. Barkhausen; 2. Rödgen; 3. Inden-Altdorf; 4. Hedemünden; 5. Pommern and Karden, oppidum Martberg; 6. Metz, rue Paille-Maille; 7. Mayen, Brückenstraße; 8-9. Utrecht, Sportpark Terweide; 10. Nenndorf. (1. Schaaff 2010: fig. 2:3; 2. Simon 1961, fig. 2:40 a-b; 3. Geilenbrügge \& Schürmann 2010: fig. 69; 4. Wefers 2012b: pl. 63; 6 Asselin et al. 2017: fig. 2:3; 7. Wefers 2012a: pl. 102:548; 8-9. Mooren 2009: fig. 6:254.255; 10. Kreibig 2006: pl. 23:339.8).

From layers of the period from about 30-40 to 60-70 CE comes the fragment of a runner (Figure 8:1) from the Kastelen plateau at Augst in Switzerland (List, 2). Its lack of a broad rim is in common with the catilli of Brillerij type. However, both the upper surface and the grinding face have a straight course, according to the drawing. 


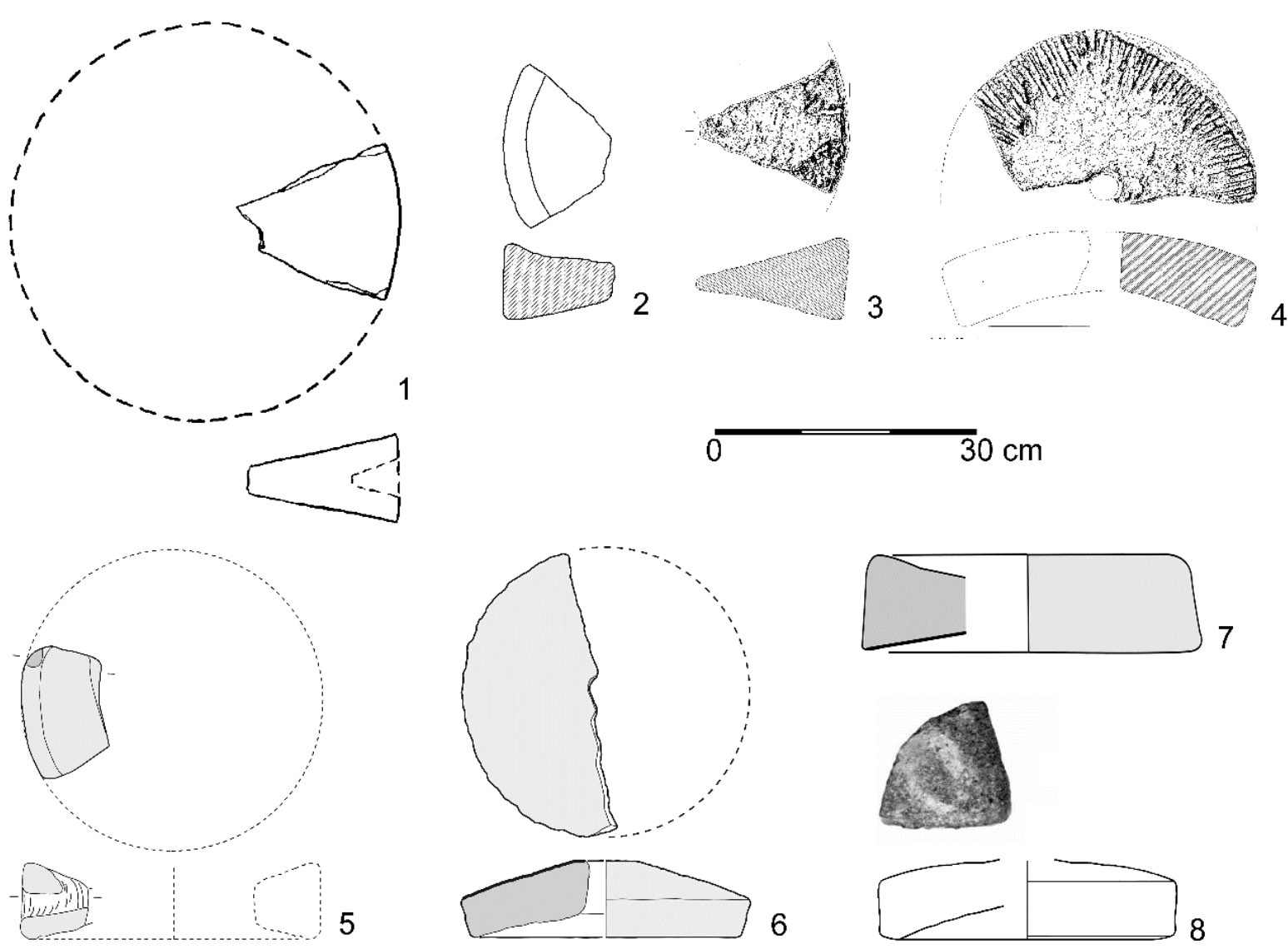

Figure 8. Quernstones of Brillerij type from Roman times. 1-3,5,7: upper stones; 4,6,8: lower stones. Provenances: 1. Augst, Kastelen; 2. Vetera near Xanten; 3-4. Briedel; 5. Hamois, Emptinne, "Champion”; 6. Meaux; 7. Bavay; 8. Avenches. (1. Schwarz 2004: fig. 128, 428; 2. Hanel 1995, pl. 164, I 19; 3-4. Joachim 1982b: pl. 8:24, 22:11; 5. van Ossel \& Defgnée 2001: fig. 145:5; 6. Lepareux-Couturier et al. 2011: fig. 27 ; 7. Picavet et al. 2011: fig. 41:66; 8. Castella \& Anderson 2004: pl. 3:64).

The Brillerij type quernstone fragments from Rasquert mentioned above (Figure 3:2) and from Nenndorf in Germany (Figure 7:10; List, 48) can be assigned to the first century CE in general. A number of further Brillerij type quernstones probably date to Roman times, though they do not come from dated features in the strict sense. In the Brückenstraße in Mayen, a catillus with a biconcave cross section made of lava was found (Figure 7:7; List, 43). In this area of the Roman vicus of Mayen no Iron Age finds are known (Glauben 2012: fig. 3). The aforementioned upper stone from Tongeren in Belgium (Figure 3:3; List, 67) comes from a context intra muros and was found together with a Roman iron trowel and ceramics, including shards of samian ware (Hartoch et al. 2015: 178). From the axial villa of Champion, "Le Rosdia", near Hamois and Emptinne in Belgium fragments of a catillus with biconcave cross section originate (Figure 8:5), as well as a meta with flat radial grooves on the slightly domed grinding surface, both of basalt lava (List, 29). They were found in pit F18.3, which lies south of the main building in an area from which no prehistoric findings are known but numerous pits containing Gallo-Belgic ware are present. Therefore, the querns most likely belong to the Roman phase of the villa.

Two quernstones from northern France are to be listed here under reserve, both from Roman cities. A runner from Bavay (Figure 8:7) is made of "volcanic rock" (Picavet et al. 2011: 221 no. 66, fig. 41:66). Its lateral face tapers slightly upwards, and the grooved grinding surface seems to be rather straight than curved. This runner would only count to type Brillerij if the latter resulted from heavy wear. From a first century context in Meaux (Figure 8:6), a 
meta is reported, with a high-arched, but only slightly curved grinding surface, whose material is described as "basalte" (List, 45). It differs from all other lower stones discussed in this study: it is thicker near the hole for the spindle than at the margin. Because of its domed grinding surface, a fragment of a meta from Avenches in Switzerland may also be assigned to the "type Brillerij" (List, 3), which is, by far, later than all other pieces. It was excavated from a context of 150 to 200-250 CE. According to the drawing (Figure 8:8), it has as a slight collar around the hole for the spindle, which is an unusual feature of querns of type Brillerij.

\subsection{Quernstones of Brillerij type which are not dated by context}

Some quernstones are interpreted as sacrificial offerings, which - sometimes in pairs were deposited in Dutch waters or bogs: in the Haaksberg veen, near Haaksbergen (Figure 9:1-3; List, 27), at Kerkenveld (List, 37), Roden (List, 61) and Valthermond (List, 69). The pair of quernstones from Löhne-Mennighüffen in Germany comes from a comparable 'wet' milieu (Figure 9:4; List, 41). In contrast to the previous examples, the fragment of a catillus found in a channel filling at Houten-Castellum (List, 34) owes its deposition to natural processes. Like the type specimen from the Brillerij (Figure 3:1; List, 12) some specimens were recovered from terps: in Englum (List, 21), Paddepoel (List, 58, 58a) and WinsumSchelum (List, 72), all in the Netherlands. Other examples of Brillerij type quernstones were found during tillage (Figure 9:5; List, 4, 13, 26), forest works (List, 19), sand extraction (Figure 10:3; List, 63) and construction works (Figure 10:1.4; List, 40, 73). A find from the Iron Age hillfort "Hunnenring” near Nonnweiler-Otzenhausen, in Germany (List, 51), cannot be assigned to the La Tène period, as there was also a Roman temple.

Several specimens come from settlement excavations in Arnhem-Schuytgraaf (List, 1), De Palen (Figure 10:5; List, 18), Houten, Schalkwijkseweg (List, 35), Noordbarge (List, 52) and Bolland near Lions (List, 10), in the Netherlands, and from the burial ground of Wederath-Belginum in Germany (Figure 10:6; List, 71). Further examples are single finds (List, 28, 70) or old collection pieces in museums (Figure 10:2.7; List, 30, 49, 66).

\section{Discussion and conclusions}

In addition to the 'classic' Brillerij type catilli, which have a concave upper surface and a concave underside, there are also specimens in which the depression of the upside is more straight-lined and those where the brim looks strangely coarse. The runners from "Fosse des Pandours" (Figure 5:8), Barkhausen (Figure 7:1), Champion (Figure 8:5), Briedel (Figure 8:3) and from the Kastelen plateau at Augst (Figure 8:1), are mainly pieces from the Roman period, and can be assigned to the straight-lined variant. On the upper stones with a coarse rim, the upper surface is not curved evenly, but shows a slight kink. The specimens from Rödgen (Figure 7:2), from Nenndorf (Figure 7:10) and from Vetera near Xanten (Figure 8:2) are all from Roman times.

The perforations for the handle sockets show a great diversity, which may be the result of using handles of various materials. Several Brillerij runners have elbow-shaped perforations for the handle (e.g., Figure 3:1-3; 6:10; 7:6, 7; 9:1-4), which would have permitted the attachment of iron clamps as known from Roman hand mills (Figure 1:2), or "a leather strap with wooden peg" as observed at one of the catilli found at Haaksberg veen (van Es \& Verlinde 1977: 76) or of a cord or piece of cloth (Alonso et al. 2014: 17, fig. 5). 

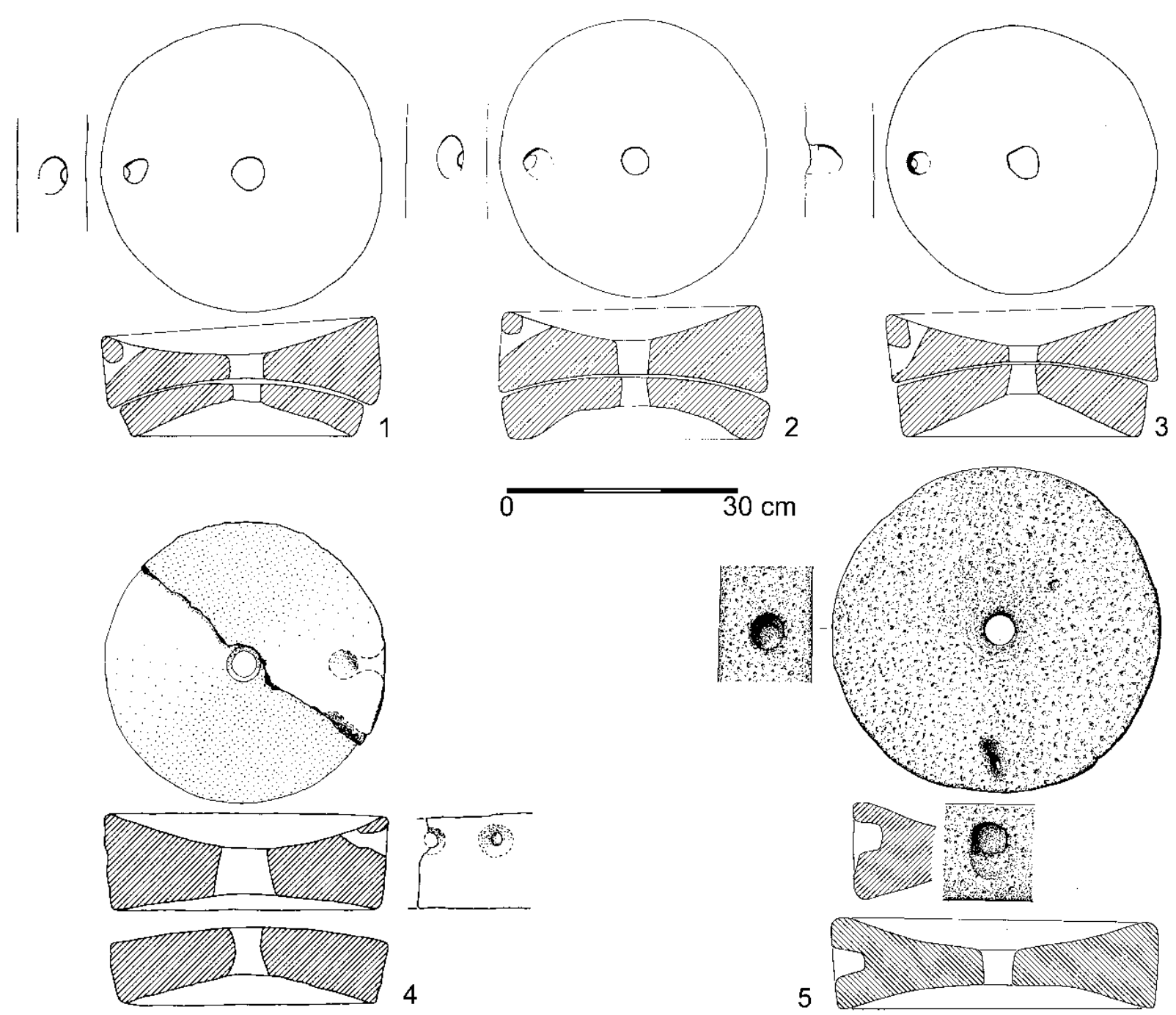

Figure 9. Quernsones of Brillerij type which are not dated by context. 1-4: upper and lower stones; 5: upper stone. Provenances: 1-3. Haaksbergen, Haaksberg veen; 4. Löhne-Mennighüffen; 5. Groesbeek. All "basalt”-like lava. (1-3. van Es \& Verlinde 1977: fig. 75; 4. Bérenger 1983: fig. 50; 5. Hulst 1987: fig. 4).

Simple horizontal holes for the handle can be found in the runners from "Fosse des Pandours" (Figure 5:8), Martberg (Figure 7:5) and perhaps from the Kastelen plateau (Figure 8:1). Such a simple form of drilling for the handle can be found even in a catillus with a relatively broad, but slightly rounded rim from a pre-Flavian well in Boxmeer-Sterckwijck in the Netherlands (Melkert 2015: 397,400, fig. 6.27).

The runners of Geldermalsen-Hondsgement (Figure 6:6) and Lierop-Boomen (Figure 10:1) have an irregularly shaped eye, possibly the result of using wedges to stabilise the rotational movement (Alonso et al. 2014: fig. 6: a, c). Some upper stones show an eye with polished margin (e.g., List, 5(1), 42), and this may indicate that they were used without a locating tab, like modern querns from Tunisia (Alonso et al. 2014: fig. 5). The same is the case with the eye of the runner from Tongeren which shows small deformations caused by wear due to the spindle (Hartoch et al. 2015: 179). Little used quernstones of Brillerij type show that the working face of the catillus clasped that of the meta, what might have contributed to their centring. 

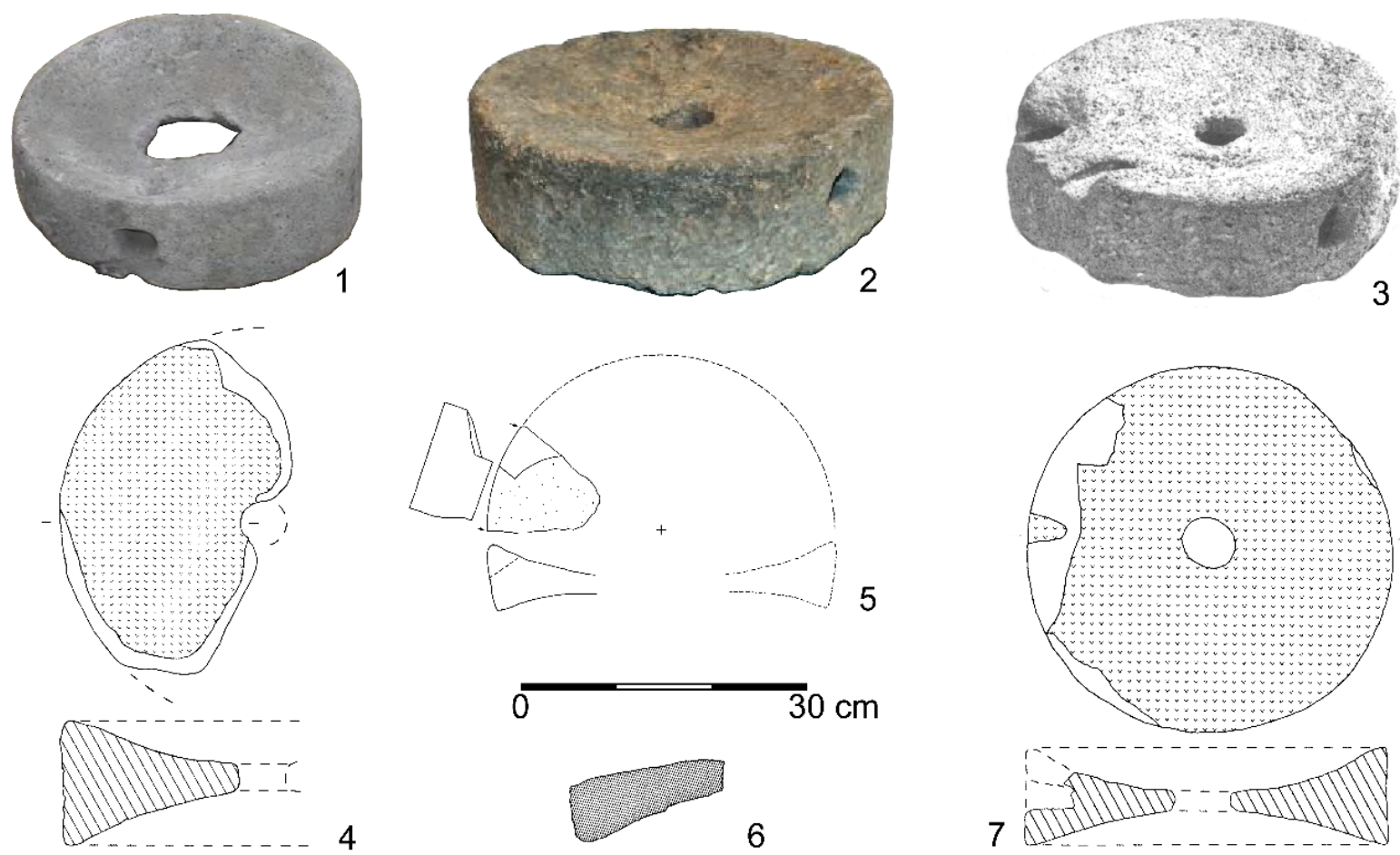

Figure 10. Quernstones of Brillerij type which are not dated by context. 1-5,7: upper stones; 6: lower stone. Provenances: 1. Lierop-Boomen; 2. Neuss; 3. Rossum; 4. Wölferlingen; 5. De Palen, 6. Wederath-Belginum; 7. Starý Kolín. All “basalt”-like lava. (1. Kortlang 2011: fig. 13; 2. Pause 2015: fig. on p. 159; 3. Modderman \& Montforts 1991: fig. 11:3; 4. Wefers 2012a: pl. 108:576; 5. Miedema 2002: fig. 179:1; 6. Cordie-Hackenberg \& Haffner 1991: pl. 472; 7. Wefers 2012a: pl. 109:A).

The querns of type Brillerij were produced in the area of the Treveri. They were supplied to the territory of the Celtic tribe of the Mediomatrici both in the La Tène period and in Roman times, but they are found also frequently in the area of Germanic tribes (Figure 11). Several specimens come from the context of Augustan military installations. The distribution range of Brillerij type quernstones resembles that of certain Late Iron Age artefacts (van Heeringen 1985, 383 note 15), such as that of rainbow-cup type staters of the northern group (Schulze-Forster 2010: fig. 5), and that of silver coins of type Scheers 57 with 'dancing man' (Roymans \& Aarts 2009: fig. 10). It is also similar to the northwestern circulation area of the glass bracelets of group Haevernick 3b (Deiters 2008: map 1). However, these distribution ranges are not completely congruent. The large number of findspots of Brillerij type quernstones in the Dutch provinces of Groningen and Drenthe has no equivalent in findspots of the aforementioned types of coins and glass armrings.

In the northeastern Netherlands, there are numerous undated querns of Brillerij type, some from Roman contexts, and no securely dated Iron Age examples. There is no evidence that querns of the Brillerij type have been exported to a nearly coinless area during the late La Tène period, but obviously some specimens were traded out of the Roman Empire. In general, the centre of the distribution area shifted northward in Roman times. At the same time the distribution also expanded to the west and to the east. In this process, small rivers could have played a role, and in the west, old routes which were newly restored. For example, Tongeren could have been reached via the Jeker (Hartoch et al. 2017: 219) while the Via Belgica would have provided a shortcut on land (Melkert 2014, 62-63). 


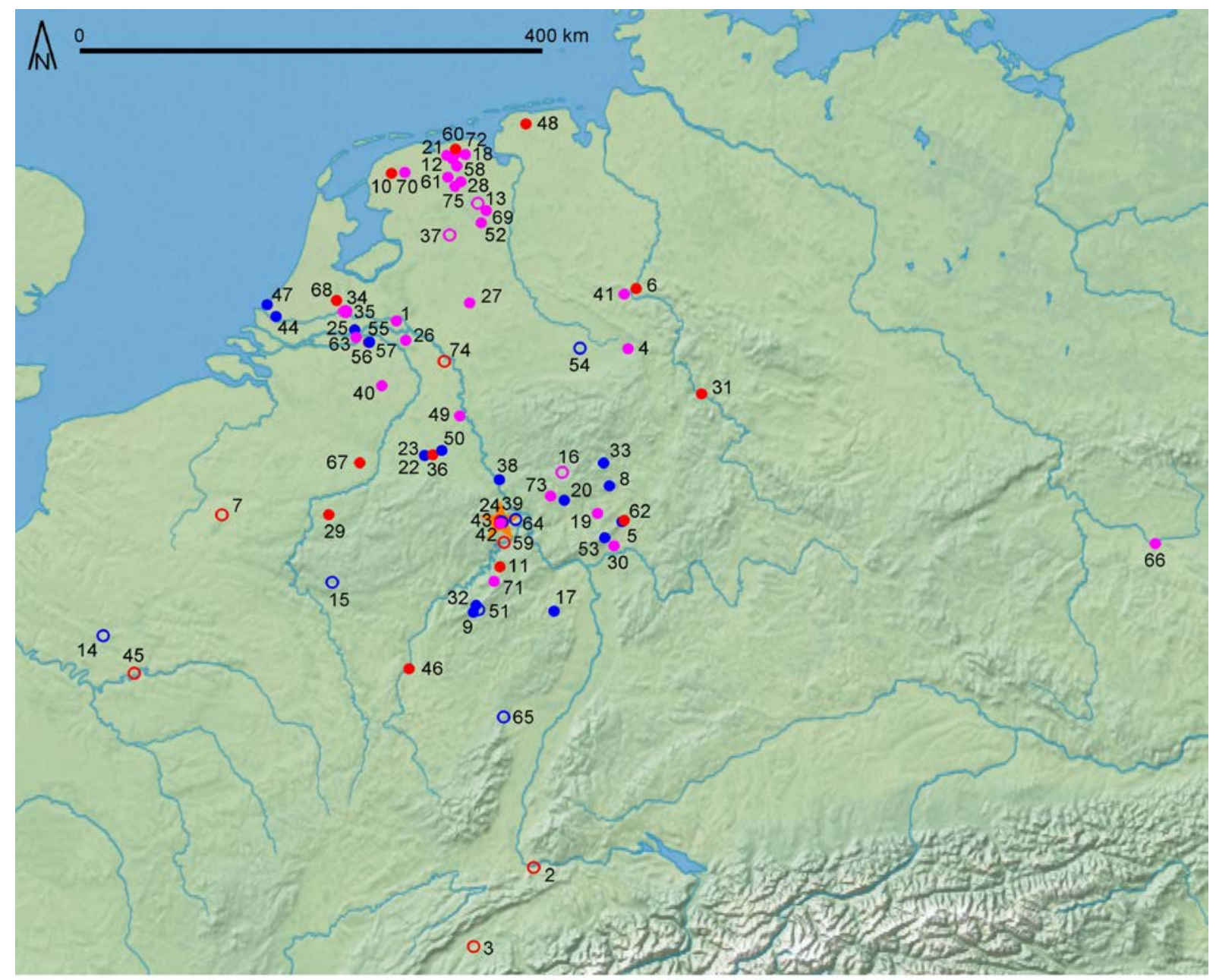

$\cdot 1 \cdot 2 \cdot 3 \circ 4 \star 5+6$

Figure 11. Localisation of findspots of Brillery type querns. Numbers refer to the supplementary list of findspots. 1. La Tène C-D; 2. undated; 3. Roman; 4. atypical, or runner, or possibliy not Mayen lava; 5. Bellerberg volcano near Mayen; 6. salt production site. Base map: Natural Earth II, version 2.0.0, NE2_HR_LC_SR_W_DR.tif

Salt was negotiated in vast quantities during the Iron Age (Salač 2006: 57). In addition to agricultural products, it may have been of particular importance in exchange for basaltic rock querns (van Heeringen 1985: 383 note 15; Simons 1987: 13) and this could explain the large number of findspots near the coast. Three findspots of Brillerij type quernstones are associated with salt production. In Bad Nauheim, "Lattkaute” (List, 5; Hansen 2016, 94-96) and Monster, "Het Geestje” (List, 47; van Heeringen 1992b, 240), salt production is proven, in Paddepoel (List, 58), it is considered possible due to briquetage (Nieuwhof 2008: 289). Already in the Hallstatt period, querns in form of Napoleon's hats arrived at the salines in the Seille Valley, so that even for this early period an exchange of lava products against salt is supposed (Hörter 1914: 288-290; Joachim 1985: 360; Mangartz 2008: 39).

Fragments of lava quernstones as well as lead pans at the Roman salter settlement of Middlewich, Cheshire, are considered to be evidence of military activity (Howard-Davis in Zant 2016, 117-119). In northern Britain, lava quernstones are mainly found on military sites of the first and second centuries (Buckley \& Major 1998: 245). In southern Britain, civilian settlements have also been supplied with these goods; notably, those with military presence received particularly many rotary querns made of basalt-like lava (Buckley \& Major 2016: 138).

To carve the curved or concave grinding faces of Brillerij type querns was much more difficult and laborious than to carve the flat conical working faces of a Roman hand mill. 
Whether there were any practical reasons for continuing to produce the ancient Celtic form in Roman times is unclear. The use of querns as offerings (van der Sanden 1998; Jodry \& Féliu 2009; Hopman 2010; 2013; Trebsche 2013; de Vries 2015) and in burial rites (Oesterwind 1997: 130-131; Gleser \& Fritsch 2015: 168) shows that these machines also had a symbolic meaning. Therefore, it was maybe important for some native groups to use querns in the traditional form. From the time after the second third of the first century there are virtually no Brillerij type quernstones recorded. This corresponds to hand-built pottery in La Tène tradition, which is detectable in the Rhineland until the second third of the first century (Lenz 1995: 159; Lenz \& Schuler 1998: 597) and started to disappear rapidly in the last third of the first century (Joachim 1999: 178). The disappearance of the Brillerij type querns and of indigenous wares are indicators of a social change that may have been significantly influenced by the outcome of the revolt of the Batavi.

\section{Acknowledgements}

For suggestions, tips, information, help or for the permission to document querns, I would like to thank Aileen Becker, Korana Deppmeyer, Erica Hanning, Peter Henrich, David Hissnauer, Moritz Jungbluth, Klaus Mages, Markus Meinen, Kuno Menchen, Bernd C. Oesterwind, Carl Pause, Hans-Hoyer von Prittwitz und Gaffron, Holger Schaaff, Yvonne Schäfer, Ralf W. Schmitz, Hans Schüller, Martina Sensburg, Benjamin Streubel, Margaret Ward and Julia Weidemüller. I would also thank Marian Melkert, an anonymous referee and Tatjana Gluhak for improving the article.

\section{References}

Alonso, N., Cantero, F.J., Jornet, R., López, D., Montes, E., Prats, G. \& Valenzuela, S. 2014, Milling wheat and barley with rotary querns: the Ouarten women (Dahmani, Kef, Tunisia). AmS-Skrifter, 24: 11-30. URL: http://am.uis.no/getfile.php/13162565/

Alonso Martínez, N. \& Pérez Jordà, G., 2014, Molins rotatius de petit format, de gran format i espais de producció en la cultura ibèrica de l'est peninsular. Revista d'Arqueologia de Ponent, 24: 239-255. (in Catalan) ("Small rotary querns, large rotary querns and areas of production in the Iberian Culture of the east of the Iberian Peninsula")

URL: http://www.rap.udl.cat/export/sites/Arqueologia/ca/.galleries/Documents/24.16_A lonsoPerez.pdf

Asselin, G., Brkojewitsch, G., Marquié, S., Maujean, J., \& Pruneyrolles, L., 2017, Outils de mouture et de broyage d'époque tibérienne: la fouille préventive de la Rue Paille-Malle à Metz (Moselle). In: Les meules du Néolithique à l'Époque médievale: technique, culture, diffusion. Actes du $2^{\text {ème }}$ colloque du Groupe Meule, Reims, du 15 au 17 mai 2014 (Buchsenschutz, O., Lepareux-Couturier, S. \& Fronteau, G., Eds.), 43ème supplément à la Revue Archéologique de l’Est. Société Archéologique de l'Est, Dijon: p. 401-406, 493-523. (in French) ("Tools for grinding and crushing of the Tiberian period: the preventive excavation of the Rue Paille-Malle in Metz (Moselle)”)

Baatz, D. 1995, Die Wassermühle bei Vitruv X 5,2. Ein archäologischer Kommentar. Saalburg Jahrbuch, 48: 5-18. (in German) ("The watermill at Vitruvius X 5.2. An archaeological commentary")

Baatz, D. 2015, Mühlsteine. In: Waldgirmes. Die Ausgrabungen in der spätaugusteischen Siedlung von Lahnau-Waldgirmes (1993 -2009) 1. Befunde und Funde (Becker, A., \& 
Rasbach, G.), Römisch-Germanische Forschungen 71. Philipp von Zabern, Darmstadt: p. 297-308. (in German) (“Quernstones”)

van Beek, R. 2009, Reliëf in tijd en ruimte: Interdisciplinair onderzoek naar bewoning en landschap van Oost-Nederland tussen de vroege prehistorie en Middeleeuwen. $\mathrm{PhD}$ thesis, Wageningen Universiteit, Wagningen, 641 p. (in Dutch) ("Relief in time and space: Interdisciplinary research into habitation and landscape of the Eastern Netherlands between early prehistoric times and the Middle Ages”) https://www.researchgate.net/publication/259801548

Bérenger, D. 1983, 181 Löhne-Menninghüffen. Ausgrabungen und Funde in WestfalenLippe, 1: 236-237. (in German) (“Site 181, Löhne-Menninghüffen”)

Bockius, R. 1992, Untersuchungen zur jüngeren Latène- und älteren römischen Kaiserzeit im Mittelrheingebiet. PhD thesis, Johannes Gutenberg - Universität Mainz, Mainz, 290 p. (in German) ("Studies of the younger La Tène period and the older Roman imperial period in the Middle Rhine area")

Boreel, G. 2017, Natursteen. In: Opgravingen te Houten-Castellum. Bewoning langs een restgeul in de IJzertijd, Romeinse tijd en Vroege Middeleeuwen (van Renswoude, J.). Zuidnederlandse Archeologische Rapporten 65. VUhbs archeologie - Vrije Universiteit, Amsterdam: p. 573-671. (in Dutch) (“Natural stone”) doi:10.17026/dans-25f-zv7y

van den Broeke, P. W., \& van Londen, H. 1995, 5000 jaar wonen op veen en klei. Archeologisch onderzoek in het reconstructiegebied Midden-Delfland. Dienst Landinrichting en Beheer Landbouwgronden, Utrecht, 52 p. (in Dutch) ("5000 years of living on peat and clay. Archaeological research in the reconstruction area MiddenDelfland")

Buckley, D. G., \& Major, H. 1998, The quernstones. In: Roman Castleford: Excavations 1974-85. Volume I: the Small Finds (Cool, H. E. M. \& Philo, C.), Yorkshire Archaeology 4. West Yorkshire Archaeology Service, Wakefield: p. 241-247.

Buckley, D., \& Major, H. 2016, Quern stones. In: Romano-British settlement and cemeteries at Mucking. Excavations by Margaret and Tom Jones, 1965-1978 (Lucy, S., Evans, Chr., Jeffries, R., Appleby, G., \& Going, Chr.), Oxbow Books, Oxford and Philadelphia: p. 131-138, 441-453.

Caesar 1917: Caesar, G. J. 1917, The Gallic War. With an English translation by H. J. Edwards. Harvard University Press, Cambridge, Mass.; W. Heinemann, London: xxii, 619 p. URL: https://archive.org/details/gallicwar00caes

Castella, D., \& Anderson, T. J. 2004, Les meules du Musée romain d'Avenches. Bulletin de l'Association Pro Aventico, 46: 115-169. (in French) ("The millstones of the Roman Museum of Avenches”) doi:10.5169/seals-246169

Cordie-Hackenberg, R., \& Haffner, A. 1991, Das keltisch-römische Gräberfeld von Wederath-Belginum, 4. Teil, Gräber 1261-1817, ausgegraben 1978-1980, Trierer Grabungen und Forschungen 6, 4. Philipp von Zabern, Mainz, 124 p. (in German) ("The gallo-roman cemetery of Wederath-Belginum, part 4, graves 1261-1817, excavated 1978-1980”)

Coutant Y., Harverson M., Ijzerman Y., \& Moog, B. 2004, Dictionary of Molinology, English - German - French - Dutch. Compiled by the Dictionary Working Group of TIMS. The International Molinological Society, Watford, Herts., 111 p. 
URL: http://www.molinology.org/pdf-

files/TIMS\%20Dictionary\%20of\%20Molinology\%20Ed01.pdf

Crawford, O. G. S., \& Röder,J. 1955, The Quern-quarries of Mayen in the Eifel. Antiquity 29, June 1955: 68-76. doi:10.1017/S0003598X00025825

Deiters, St. 2008, Haevernick Gruppe 3B - Überlegungen zu einem Glasarmringtyp der ausgehenden Eisenzeit. In: Durch die Zeiten... Festschrift für Albrecht Jockenhövel zum 65. Geburtstag (Verse, F., Knoche, B., Graefe, J., Hohlbein, M., Schierhold, K., Siemann, C., Uckelmann, M., \& Woltermann G., Eds.), Studia Honoraria 28. Leidorf, Rahden in Westfalen: p. 315-337. (in German) ("Haevernick Group 3B - Reflections on a glass-armring type of the late Iron Age”)

Engels, H. J. 1976, Der Donnersberg I. Die Viereckschanze. Grabung 1974/75. Steiner, Wiesbaden, 48 p., 41 pl. (in German) ("The Donnersberg I. The square ditched enclosure. Excavation 1974/75”)

Enzmann, J. 2016, Die Verbreitung der Drehmühlen aus Eifeler Basaltlava im nordwesteuropäischen Barbaricum während der Römischen Kaiserzeit. Master thesis in the field of Prehistoric and Historical Archeology of the Philosophical Faculty of the Christian-Albrechts-Universität, Kiel, 245 p. (in German) ("The distribution of rotary querns from Eifel basalt lava in the northwest European Barbaricum during the Roman Empire")

van Es, W. A., \& Verlinde, A. D. 1977, Overijssel in Roman and Early-Medieval Times, Berichten van de Rijksdienst voor het Oudheidkundig Bodemonderzoek, 27: 7-89.

URL: https://easy.dans.knaw.nl/ui/datasets/id/easy-dataset:32833

Fémolant, J.-M. 1989, L'établissement rural gaulois de La Tène finale de Creil (Oise). Revue archéologique de Picardie, 3(1): 43-66. (in French) ("The rural Gaulish settlement of the Late La Tène culture of Creil (Oise)”) doi:10.3406/pica.1989.1552

Fuchshofen, St., \& Geilenbrügge, U. 2010, Die späteisenzeitliche Befestigung von VilichMüldorf und Siedlungen der Metallzeiten im Indetal bei Altdorf. In: Fundgeschichten Archäologie in Nordrhein-Westfalen (Otten, T., Hellenkemper, H., Kunow, J. \& Rind M., Eds.), Schriften zu Bodendenkmalpflege in Nordrhein-Westfalen, Vol. 9. Philipp von Zabern, Mainz: p. 92-96. (in German) ("The Late Iron Age fortification of VilichMüldorf and settlements of metal times in the valley of the Inde at Altdorf”)

Gechter, M. 1987, Xanten WES. Die Legionslager Vetera I und II. In: Die Römer in Nordrhein-Westfalen (Horn, H. G., Ed.), Theiss, Stuttgart: p. 619-625. (in German) ("Xanten WES (= district of Wesel). The legionary camps Vetera I and II”)

Geilenbrügge, U., \& Schürmann, W. 2010, Die älteste Wassermühle Mitteleuropas im Indetal bei Altdorf? In: Archäologie im Rheinland 2009. Theiss, Stuttgart: p. 62-64. (in German) (“The oldest watermill in Central Europe in the Indetal near Altdorf?”)

Giljohann, R., Hunold, A., \& Wenzel, St. 2017, Rural life and industry between the Eifel and the Rhine. In: Gallia Rustica. Les campagnes du Nord-Est de la Gaule, de la fin de l'âge du fer à l'Antiquité tardive (Reddé, M., Ed.), Mémoires Vol. 49. Ausonius Éditions, Bordeaux: p. 125-152.

Glauben, A. M. 2012, Der vicus von Mayen (Lkr. Mayen-Koblenz). Alte Grabungen und neue Forschungen. In: Römische Landnutzung in der Eifel. Neue Ausgrabungen und Forschungen. Tagung in Mayen, vom 3. bis zum 6. November 2011 (Grünewald, M. \& Wenzel, St., Eds.), RGZM-Tagungen 16. Verlag des Römisch-Germanischen 
Zentralmuseums, Mainz: p. 87-98. (in German) ("The vicus of Mayen. Old excavations and new research”)

Gleser, R., \& Fritsch T. 2015, Eine neu entdeckte spätrepublikanische Amphore im Umfeld des keltischen Oppidums "Hunnenring" bei Otzenhausen - Die Grabungen 2013 im Brandgräberfeld Bierfeld "Vor dem Erker", Gem. Nonnweiler, Kr. St. Wendel, Saarland. In: Archäologie in der Großregion. Beiträge des internationalen Symposiums zur Archäologie in der Großregion in der Europäischen Akademie Otzenhausen vom 7. - 9. März 2014 (Koch, M., Ed.), Archäologentage Otzenhausen 1, Europäische Akademie Otzenhausen, Nonnweiler 2015: p. 149-172. (in German) (“A newly discovered late republican amphora in the environment of the Celtic oppidum "Hunnenring" near Otzenhausen - The excavations 2013 in the cemetery Bierfeld "Vor dem Erker", municipality of Nonnweiler, district of St. Wendel, Saarland”)

URL: https://www.eao-

otzenhausen.de/fileadmin/user_upload/EAO/Content_Bildungszentrum_Dokumente/Ar chaeologentage_Band_1/ArchTage2014\%20Gleser,\%20Fritsch.pdf

Gluhak, T. M. 2010, Mühlen für das römische Militär. Geochemische Herkunftsanalysen von Mühlsteinen aus den augusteischen Lagern von Haltern, Oberaden, Anreppen und Barkhausen. Archäologisches Korrespondenzblatt, 40(2): 273-284. (in German) ("Mills for the Roman army - geochemical provenance analyses of millstones from the Augustan fortresses Haltern, Oberaden, Anreppen and Barkhausen”)

Gluhak, T. M., \& Hofmeister, W. 2009, Roman lava quarries in the Eifel region (Germany): geochemical data for millstone provenance studies. Journal of Archaeological Science, 36(8): 1174-1182. doi:10.1016/j.jas.2009.04.007

Gluhak T. M., \& Wefers, S. 2011, Geochemische Herkunftsbestimmung römischer Getreidemühlen vom Magdalensberg, Kärnten. In: Secundus conventus austriacus archaeometriae : Tagungsband zum Zweiten Österreichischen Archäometriekongress, 13. - 14. Mai 2010 (Cemper-Kiesslich J., Lang F., Moser, S., Schaller K., Uhlir, Chr., \& Unterwurzacher M., Eds.), ArchaeoPlus - Schriften zur Archäologie und Archäometrie an der Paris Lodron-Universität Salzburg, Vol. 4. Universität Salzburg, Interfakultärer Fachbereich Gerichtsmedizin, Salzburg: p. 79-82. (in German) ("Geochemical provenance determination of Roman flour mills from the Magdalensberg, Carinthia”)

Green, Chr. 2017, Querns and millstones in Late Iron Age and Roman London and SouthEast England. In: Agriculture and Industry in South-Eastern Roman Britain (Bird, D., Ed.), Oxbow Books, Oxford \& Philadelphia: p. 156-179.

Günther, K. 1983, 240 Bad Lippspringe. Ausgrabungen und Funde in Westfalen-Lippe, 1: 265-266. (in German) (“Site 240, Bad Lippspringe”)

Haberey, W., \& Rest, W. 1941, Vorgeschichtliche und frühmittelalterliche Siedlungsreste in Kottenheim, Kreis Mayen. Bonner Jahrbücher, 146: 395-403. (in German) ("Prehistoric and Early Medieval settlement remains in Kottenheim, district of Mayen”)

Hanel, N. 1995, Vetera I. Die Funde aus den römischen Lagern auf dem Fürstenberg bei Xanten. Mit einem Beitrag von T. Rehren. Rheinische Ausgrabungen 35. RheinlandVerlag and R. Habelt, Köln and Bonn 1995, Vol. 1: 353 p., 169 pl., 5 plans; Vol. 2: 763 p., 7 plans. (in German) ("Vetera I. The finds from the Roman camps on the Fürstenberg near Xanten”)

Hansen, L. 2016, Die latènezeitlichen Saline von Bad Nauheim. Die Befunde der Grabungen der Jahre 2011-2004 in der Kurstraße 2. Fundberichte aus Hessen, Beiheft 8; Glauberg- 
Forschungen 1. Landesamt für Denkmalpflege Hessen, Wiesbaden, 283 p., 3 supplements (in German) ("The La Tène saline of Bad Nauheim. The features of the excavations of the years 2011-2004 in Kurstraße 2")

Harsema, O. H. 1967, Geïmporteerde basaltlava maalstenen uit de Romeinse tijd uit Groninger wierden. Varia bio-archaeologica, 31, = Groninger oudheden, 9; = overdruk uit Groningse Volksalmanak 1967: 139-158. (in Dutch) ("Imported querns of basalt lava from the Roman period from Groninger terps”)

Harsema, O. H. 1979, Maalstenen en handmolens in Drenthe van het neolithicum tot ca. 1300 A.D. In: Molens in Drenthe (Bicker Caarten, A., Blaauw, H., Heringa J., Janssen, C. F., de Koning, A. J., van Opijnen, W. A., van Uchelen, J. A., \& van der Veen Czn, B., Red.), Uitgeverij Wanders, Zwolle, and J. A. Boom en Zoon, Meppel: p. 10-45. (in Dutch) (“Querns and hand-mills in Drenthe from the Neolithic to ca. 1300 AD”)

den Hartog, C. M. W. 2009, Sportpark Terweide 2. LR41-42: Archeologisch onderzoek Sportpark Terweide. Basisrapportage Archeologie 18, Gemeente Utrecht, Utrecht, 149 p., 7 supplements. (in Dutch) ("Sportpark Terweide 2. LR41-42: Archaeological investigation Sportpark Terweide”)

URL: https://www.utrecht.nl/fileadmin/uploads/documenten/wonen-en-leven/vrijetijd/erfgoed/BrA_18_Sportpark_Terweide_2_1_.pdf

Hartoch, E., Doperé, F., Dreesen, R., Gluhak, T. M., Goemaere, E., Manteleers, I., Van Camp, L., \& Wefers, S. (Eds.), 2015, Moudre au Pays des Tungri, Atuatuca Vol. 7, Publications of the Gallo-Roman Museum of Tongeren, Tongeren, 416 p. (in French) ("Milling in the land of the Tungri")

Hartoch, E., Gluhak, T., Dreesen, R., \& Goemaere, E. 2017, "Where does your Saddle Quern come from?” Grinding in the Contemporary Province of Limburg (BE) during the Iron Age. In: The Exploitation of Raw Materials in Prehistory: Sourcing, Processing and Distribution (Pereira, T., Terradas, X., \& Bicho, N. Eds.), Cambridge Scholars Publishing, Newcastle upon Tyne, p. 205-221.

van Heeringen, R. M. 1985, Typologie, Zeitstellung und Verbreitung der in die Niederlande importierten vorgeschichtlichen Mahlsteine aus Tephrit. Archäologisches Korrespondenzblatt, 15(3): 371-383. (in German) ("Typology, dating and distribution of prehistoric querns of tephrite imported into the Netherlands")

van Heeringen, R. M., 1992a, The Iron Age in the Western Netherlands III: Site Catalogue and Pottery Description. Map Sheet 2. Berichten van de Rijksdienst voor het Oudheidkundig Bodemonderzoek, 39, 1989 (1992): 7-67. doi:10.17026/dans-x69-n962

van Heeringen, R. M., 1992b, The Iron Age in the Western Netherlands V: Synthesis. With an appendix by G. F. IJzereef, F. J. Laarman and R. C. M. G. Lauwerier. Berichten van de Rijksdienst voor het Oudheidkundig Bodemonderzoek, 39, 1989 (1992): 157-267.

Hill, J., Peacock, D., \& Williams, D. 2011, Evidence for grain processing and storage. In: Roman London and the Walbrook stream crossing. Excavations at 1 Poultry and vicinity, City of London, part 2 (Hill, J., \& Rowsome, P., Eds.), MOLA Monograph 37. Museum of London Archaeology, London: p. 349-353, 571-587.

Hörter, F. jun. 1994, Getreidereiben und Mühlsteine aus der Eifel. Ein Beitrag zur Steinbruch- und Mühlsteingeschichte. Geschichts- und Altertumsverein Mayen, Mayen, 192 p. (in German) ("Saddle querns and millstones from the Eifel. A contribution to the history of quarries and millstones”) 
Hörter, F. jun. 2000, Vom Reibstein zur römischen Kraftmühle. In: Steinbruch und Bergwerk. Denkmäler römischer Technikgeschichte zwischen Eifel und Rhein. Kataloghandbuch zu den Ausstellungen in den Museen von Mayen und Andernach (Bockius, R., Bosinski, G., Hörter, F., Hunold, A., Mangartz, F., Oesterwind, B. C., Schaaff, H., \& Schäfer, K.), Vulkanpark-Forschungen 2, Verlag des Römisch-Germanischen Zentralmuseums, Mainz: p. 58-70, 155-160. (in German) ("From saddle quern to Roman millstone”)

Hörter, F. sen., Michels, F.-X., \& Röder, J. 1951, Die Geschichte der Basaltlava-industrie von Mayen und Niedermendig. I: Vor- und Frühgeschichte. Jahrbuch für Geschichte und Kunst am Mittelrhein, 2/3, 1950/51 (1951): 1-32, pl 1-3. (in German) ("The history of the basalt lava industry of Mayen and Niedermendig. I: Prehistory and Protohistory”)

Hörter, F. sen., Michels, F.-X., \& Röder, J. 1955, Die Geschichte der Basaltlava-industrie von Mayen und Niedermendig. II: Mittelalter und Neuzeit. Jahrbuch für Geschichte und Kunst am Mittelrhein, 6/7, 1954/55 (1955): 7-33, 1 supplement. . (in German) ("The history of the basalt lava industry of Mayen and Niedermendig. II: Middle Ages and early modern times”)

Hörter, P. 1914, Die Basaltlava-Industrie bei Mayen (Rheinland) in vorrömischer und römischer Zeit. Mannus, 6: 283-294, pl. 12-15. (in German) ("The basalt lava industry near Mayen (Rhineland) in pre-Roman and Roman times”)

Holodňák, P. 2001, Experiment s mletím obilnin na žernovech tzv. řeckého typu. Experiment mit dem Mahlen des Getreides an den Mahlsteinen des sog. griechischen Typs (Balkenhandmühlen). Archeologické rozhledy, 53(1): 31-44. (in Czech) ("Experiment with grinding cereals on the so-called greek type”) URL: http://www.arup.cas.cz/wpcontent/uploads/2010/11/2001_1.pdf

Holtmeyer-Wild, V. 2000, Vorgeschichtliche Reibsteine aus der Umgebung von Mayen. Reibsteine aus Basaltlava. Vulkanpark-Forschungen 3. Verlag des RömischGermanischen Zentralmuseums, Mainz, 90 p. (in German) ("Prehistoric saddle querns from the surroundings of Mayen. Saddle querns from basalt lava”)

Hopman, E. C. 2010, Malen over breuken: het ritueel gebruik van roterende handmolens. Een onderzoek naar IJzertijd/Romeinse tijd fragmenten uit de Noordelijke Nederlanden. Bachelor thesis of the Rijksuniversiteit Groningen, Groningen, 114 p. (in Dutch) ("Grinding before breaking: the ritual use of rotary querns. An investigation into fragments of the Iron Age/Roman times from the Northern Netherlands”)

Hopmann, E. C. 2013, IJzertijd handmolens in de noordelijke provincies: een ritueel gebruik? Paleo-aktueel, 24: 77-82. (in Dutch) ("Iron Age querns in the northern provinces: a ritual use?”)

Hornung, S. 2016, Siedlung und Bevölkerung in Ostgallien zwischen Gallischem Krieg und der Festigung der römischen Herrschaft. Eine Studie auf Basis landschaftsarchäologischer Forschungen im Umfeld des Oppidums “Hunnenring” von Otzenhausen (Lkr. St. Wendel), Römisch-Germanische Forschungen 73. Philipp von Zabern, Darmstadt, 601 p. (in German) ("Settlement and population in Eastern Gaul between the Gallic War and the consolidation of Roman rule. A study based on landscape archaeological research in the environment of the oppidum "Hunnenring" at Otzenhausen (district of St. Wendel)")

Hornung, S., Gluhak, T. M., \& Kronz, A. 2015, Die Provenienz der Mühlsteinfragmente aus dem spätrepublikanischen Militärlager von Hermeskeil (Lkr. Trier-Saarburg) - eine 
Brücke zur historischen Überlieferung? Archäometrie und Denkmalpflege 2015, 25.-28. März 2015, Mainz. Metalla, Sonderheft 7: 126-128. (in German) ("The provenance of the quernstone fragments from the late republican military camp of Hermeskeil (district of Trier-Saarburg) - a bridge to the historical tradition?”)

Hulst, R. S. 1987, Archeologische Kroniek van Gelderland 1986. Bijdragen en mededelingen van de Vereniging Gelre, 78: 207-224. (in Dutch) (“Archaeological chronicle of Gelderland 1986”)

Hunold, A. 2002: Altes und Neues aus dem römischen Mayen: eine neue Karte zur Topographie des vicus. Acta Praehistorica et Archaeologica, 34: 69-82. (in German) ("Old and new from the Roman Mayen: a new map of the topography of the vicus")

Jaccottey, L., \& Farget, V. 2011, Les normes de dessin des meules rotatives. In: Évolution typologique et technique des meules du Néolithique à l'an mille. Actes des IIIe Rencontres Archéologiques de l'Archéosite gaulois (Buchsenschutz, O., Jaccottey, L., Jodry, F., \& Blanchard, J.-L., Eds.), Aquitania Supplément 23. Féderation Aquitania, Bordeaux: 51-68. (in French) (“The norms for drawing rotary querns and millstones”)

Jaccottey, L., Alonso, N., Defressigne, S., Hamon, C., Lepareux-Couturier, S., Brisotto, V., Galland-Crety, S., Jodry, F., Lagadec, J.-P., Lepaumier, H., Longepierre, S., Milleville, A., Robin, B., \& Zaour, N. 2013, Le passage des meules va-et-vient aux meules rotatives en France. In: L'âge du Fer en Europe. Mélanges offerts à Olivier Buchsenschutz (Krausz, S., Colin, A., Gruel, K., Ralston, I., \& Dechezleprêtre, T., Eds.), Ausonius Éditions, collection Mémoires 32. Ausonius Éditions, Bordeaux: p. 405-419. (in French) ("The transition from saddle querns to rotary querns in France”)

Jansma, E., Haneca, K., \& Kosian, M. 2014, A dendrochronological reassessment of three Roman boats from Utrecht (the Netherlands): evidence of inland navigation between the lower-Scheldt region in Gallia Belgica and the limes of Germania Inferior. Journal of Archaeological Science, 50: 484-496. doi:10.1016/j.jas.2014.07.019

Joachim, H.-E. 1980, Jüngerlatènezeitliche Siedlungen bei Eschweiler, Kr. Aachen. Mit Beiträgen von K.-H. Knörzer und J. Schalich. Bonner Jahrbücher, 180: 355-459. (in German) ("Settlements of the late La Tène culture near Eschweiler, district of Aachen”)

Joachim, H.-E. 1982a, Ausgrabungen auf dem Petersberg bei Königswinter, Rhein-SiegKreis. Bonner Jahrbücher, 182: 393-439. (in German) ("Excavations on the Petersberg near Königswinter, Rhein-Sieg-Kreis”)

Joachim, H.-E. 1982b, Eisenzeitliche und römische Hügelgräber bei Briedel, Kreis CochemZell. Trierer Zeitschrift, 45: 65-195. (in German) ("Iron Age and Roman tumuli near Briedel, district of Cochem-Zell”)

Joachim, H.-E. 1985, Zu eisenzeitlichen Reibsteinen aus Basaltlava, den sogenannten Napoleonshüten. Archäologisches Korrespondenzblatt, 15(3): 359-369. (in German) ("On the Iron Age saddle querns of basalt lava, the so called Napoleon's hats")

Joachim, H.-E. 1999, Einheimische vorcoloniazeitliche Keramik aus dem Bereich der Colonia Ulpia Traiana (CUT) bei Xanten. In: Xantener Berichte, Vol. 8. Rheinland-Verlag, Köln: p. 173-199. (in German) ("Indigenous pre-colonial pottery from the area of the Colonia Ulpia Traiana (CUT) near Xanten”)

Joachim, H.-E. 2006, Niederzier-Hambach, Kreis Düren. Befestigte Siedlung der Spätlatènezeit. In: Urgeschichte im Rheinland (Kunow, J. \& Wegner, H.-H., Eds.), Jahrbuch 2005 des Rheinischen Vereins für Denkmalpflege und Landschaftsschutz. 
Verlag des Rheinischen Vereins für Denkmalpflege und Landschaftsschutz, Köln: p. 447-448. (in German) ("Niederzier-Hambach, district of Düren. Fortified settlement of the Late La Tène period”)

Joachim, H.-E. 2009, Die Datierung der jüngerlatènezeitlichen Siedlung von NiederzierHambach im Kreis Düren. Bonner Jahrbücher, 207, 2007 (2009): 33-74. (in German) ("Dating of the Late La Tène settlement of Niederzier-Hambach in the district of Düren”) doi:10.11588/bjb.2007.0.44025

Jodry, F., \& Féliu, C. 2009, Nouvelles données sur les dépôts de meules rotatives. Deux exemples de La Tène Finale en Alsace. In: Du matériel au spirituel: Réalités archéologiques et historiques des 'dépôts' de la Préhistoire à nos jours (Bonnardin, S., Hamon, C., Lauwers, M. \& Quilliec, B. (Eds.), Actes des XXIXe Rencontres Internationales d'Archéologie et d'Histoire d'Antibes, Antibes, Editions APDCA: p. 6976. (in French) ("New information on deposits of rotary mills. Two examples of the Late La Tène culture in Alsace”)

Kalis A. J., \& Meurers-Balke, J. 2007, Landnutzung im Niederheingebiet zwischen Krieg und Frieden. In: Begleitbuch zur Ausstellung 'Krieg und Frieden. Kelten - Römer Germanen' im Rheinischen Landesmuseum Bonn, 21.6.2007-6.1.2008 (Uelsberg, G., Ed.), Primus Verlag, Darmstadt: p. 144-153. (in German) ("Land use in the Lower Rhine region between war and peace”)

Kars, H. 1983, Een maalsteenproduktiecentrum bij Mayen in de Eifel. Grondboor \& Hamer, 37(3/4), 110-120. (in Dutch) (“A centre for millstone production near Mayen in the Eifel”) URL: http://natuurtijdschriften.nl/download?type=document\&docid=405238

Knippenberg, S. 2011, Natuursteen. In: Een cultusplaats in Oss. Opgraving van een ijzertijd nederzetting en cultusplaats aan de Brabantstraat (de Leeuwe, R.), Archol Rapport 123. Archol, Leiden: p. 94-102. (in Dutch) ("Natural stone”)

Kortlang, F. P. 2011, De Archeologiekaart van Someren. Een archeologische waarden- en beleidskaart voor de gemeente Someren. ArchAeO-Rapport 0913. ArchAeO, Eindhoven, 120 p. (in Dutch) ("The Archeology map of Someren. An archaeological value and policy map for the municipality of Someren”)

URL: https://www.someren.nl/fileadmin/Someren/PDF_formulieren_producten/Beleid/ Milieu_en_water/Nota_archeologiebeleid_2012/Archeologiekaart_van_Someren.pdf

Kreibig, N. 2006, Die bronze- und kaiserzeitliche Siedlung von Nenndorf, Ldkr. Wittmund, Beiträge zur Archäologie in Niedersachsen 11. Leidorf, Rahden in Westfalen, 200 p. (in German) ("The settlement of the Bronze Age and of Imperial times of Nenndorf, district of Wittmund")

Kreuz, A. \& Baatz D. 2003, Try and error. Gedanken und Erfahrungen zum Darren und Entspelzen von Getreide in den Jahrhunderten um Christi Geburt. Denkmalpflege und Kulturgeschichte, 1/2003: 20-25. (in German) ("Try and error. Thoughts and experiences about the drying and dehusking of grain during the centuries around the birth of Christ”) 
Krist, J.S., de Voogd, J.B., \& Schoneveld, J. 2001, Een vindplaats uit de Late IJzertijd en Vroeg-Romeinse Tijd aan de Schalkwijkse weg te Houten, terrein 14, Provincie Utrecht. Met bijdragen van J. L. van Beek, H. Buitenhuis, B. Bijl, M. Essink, C. G. Koopstra, M. J. L. Th. Niekus, G. J. de Roller \& A. Ufkes. ARC-Publicaties 48. Archaeological Research \& Consultancy, Groningen, 216 p. (in Dutch) (“A site from the Late Iron Age and Early Roman Period on the Schalkwijkse weg in Houten, terrain 14, Province of Utrecht”)

de Langen, G. J., Perger, T., Prummel W., Schelvis, I., Taayke, E., Willemsen, J., \& Wispelwey, M. 1994, Een korte verkenning te Bolland bij Lions. Paleo-Aktueel, 5: 7479. (in Dutch) (“A short exploration in Bolland near Lions”)

Lanting, J. N., \& van der Plicht, J. 2006, De 14C-chronologie van de Nederlandse pre- en protohistorie V: midden-en late Ijzertijd. Palaeohistoria, 47/48, 2005/2006 (2006): 241427. (in Dutch) ("The 14C-chronology of the Dutch pre- and protohistory V: middle and late Iron Age”) URL: http://rjh.ub.rug.nl/Palaeohistoria/article/view/25145/22599

de Leeuwe, R. 2011, Een cultusplaats in Oss. Opgraving van een ijzertijd nederzetting en cultusplaats aan de Brabantstraat, Archol Rapport 123. Archol, Leiden, 180 p. (in Dutch) (“A cult place in Oss. Excavation of an Iron Age settlement and ritual place in the Brabantstraat”)

Lenz, K. H. 1995, Germanische Siedlungen der Spätlatènezeit und der Römischen Kaiserzeit im rheinischen Braunkohlenrevier. Archäologische Informationen, 18 (2): 157-162. (in German) ("Germanic settlements of the Late La Tène period and of Roman Imperial times in the Rhenish lignite area")

Lenz, K. H., \& Schuler, A. 1998, Handgeformte Gefäßkeramik der frühen Römischen Kaiserzeit aus Bornheim-Sechtem, Rhein-Sieg-Kreis. Zum Übergang vom Spätlatène zur Römischen Kaiserzeit im südlichen Niederrheingebiet. Archäologisches Korrespondenzblatt, 28(4): 587-599. (in German) ("Hand-built pottery of early Roman imperial times from Bornheim-Sechtem, Rhein-Sieg-Kreis. On the transition from the late La Tène period to Roman imperial times in the southern Lower Rhine region”)

Lepareux-Couturier, S. 2011, Les meules gallo-romaines du chef-lieu de la cité des Meldes (Meaux, Seine-et-Marne), première approche. In: Évolution typologique et technique des meules du Néolithique à l'an mille. Actes des IIIe Rencontres Archéologiques de l'Archéosite gaulois (Buchsenschutz, O., Jaccottey, L., Jodry, F., \& Blanchard, J.-L., Eds.), Aquitania Supplément 23, Féderation Aquitania, Bordeaux: p. 409-433. (in French) ("The Gallo-Roman millstones of the capital of the state of the Meldes (Meaux, Seine-et-Marne), first approach”)

Lepareux-Couturier, S., Robin, B., Buchsenschutz, O., \& Fronteau, G. 2017, Évolution des meules rotatives de l'âge du Fer au Moyen Âge en France : exploitation de la base de données du PCR Meule. In: Les meules du Néolithique à l'Époque médievale:

technique, culture, diffusion. Actes du $2^{\text {ème }}$ colloque du Groupe Meule, Reims, du 15 au 17 mai 2014 (Buchsenschutz, O., Lepareux-Couturier, S., \& Fronteau, G., Dir.) $43^{\text {ème }}$ supplément à la Revue Archéologique de l'Est, Société Archéologique de l'Est, Dijon, 317-335, 493-523. (in French) ("Evolution of the rotary mills from the Iron Age to the Middle Ages in France: utilisation of the database of PCR Meule”)

Lung, W. 1962, Kottenheim. Ein Dorf und seine Landschaft. Mit Beiträgen von A. Pickel, A. Hoffmann, J. Schmitz und W. Schweitzer. Louis Schreder, Mayen, 192 p. (in German) ("Kottenheim. A village and its landscape") 
MacKie, E. W. 2007, Rotary quernstones. In: Elginhaugh: A Flavian fort and its annexe (Hanson, W. S., Speller, K., Yeoman, P. A., \& Terry, J.), Britannia Monograph Series 23. Society for the Promotion of Roman Studies, London 2007: p. 492-510.

Mangartz, F. 2007, Een 'logboek' voor De Meern 1: beschrijving en determinatie van de herkomst van de natuursteen. In: Een Romeinse Rijnaak, gevonden in Utrecht-De Meern. Resultaten van het onderzoek naar de platbodem 'De Meern 1' (Jansma, E. \& Morel, J.-A. A. W., Red.), Rapportage Archeologische Monumentenzorg 144 A. Rijksdienst voor Archeologie, Cultuurlandschap en Monumenten, Amersfoort: p. 245255, pl. 88. (in Dutch) (“A 'logbook' for De Meern 1: description and determination of the origin of the natural stone”)

Mangartz, F. 2008, Römischer Basaltlava-Abbau zwischen Eifel und Rhein, Monographien des Römisch-Germanisches Zentralmuseum 7; Vulkanpark Forschungen 7. RömischGermanisches Zentralmuseum, Mainz, 335 p. (in German) ("Roman basalt lava quarrying between Eifel and Rhine”)

Mangartz, F. 2012, Römerzeitliche Mühlsteinproduktion in den Grubenfeldern des Bellerberg-Vulkans bei Mayen (Lkr. Mayen-Koblenz). In: Römische Landnutzung in der Eifel. Neue Ausgrabungen und Forschungen. Tagung in Mayen, vom 3. bis zum 6 . November 2011 (Grünewald, M. \& Wenzel, St., Eds.), RGZM-Tagungen 16. Verlag des Römisch-Germanischen Zentralmuseums, Mainz: p. 1-24. (in German) ("Roman millstone production in the quarry area of the Bellerberg volcano near Mayen (district of Mayen-Koblenz)”)

Matthys, A., \& Hossey, G. 1979, L'oppidum du "Trînchi” à Cugnon, Archaeologia Belgica 215. Service national des fouilles, Bruxelles, 23 p., 3 pl. (in French) ("The oppidum of "Trînchi” at Cugnon”)

Melkert, M. J. A. 2014, Natuursteen en vloerfragmenten. In: Langs de Romeinse weg in Rimburg. Een noodopgraving uit 1970 (Veldman, H.A.P.), ADC Rapport 3713. ADC ArcheoProjecten, Amersfoort: p. 51-63. (in Dutch) ("Natural stone and floor fragments”)

Melkert, M. J. A. 2015, Natursteen. In: De archeologie van Boxmeer-Sterckwijck: 4500 jaar wonen, werken en begraven langs de Maas (Blom, E., \& van der Velde, H. M., Red.), ADC Monografie 18. ADC ArcheoProjecten, Amersfoort: p. 394-412. (in Dutch) (“Natural stone”)

Miedema, M. 2002, West-Fivelingo 600 v. Chr. - 1900 n. Chr.: Archeologische kartering en beschrijving van 2500 jaar bewoning in Midden-Groningen. Palaeohistoria 41/42, 1999-2000 (2002): 237-445. (in Dutch) ("West Fivelingo 600 BC - 1900 AD: Archeological mapping and description of 2500 years of habitation in Central Groningen”) URL: http://rjh.ub.rug.nl/Palaeohistoria/article/view/24991

Milne, G., \& Wardle, A. 1996, Early Roman development at Leadenhall Court, London and related research. With contributions by I. Belts, J. Bird, M. Crowley, B. Davies, A. Davis, J. Groves, C. Harrison, F. Pritchard, J. Shepherd and B. West. Transactions of the London and Middlesex Archaeol Society, 44,1993: 23-169.

URL: http://www.colat.org.uk/assets/doc/early-roman-leadenhall-court.pdf

Modderman, P. J. R., \& Montforts, M. J. G. Th. 1991, Archeologische kroniek van Gelderland, 1970-1984. Bijdragen en Mededelingen van de Vereniging Gelre, 82: 143188. (in Dutch) (“Archaeological chronicle of Gelderland, 1970-1984”) 
Mooren, S. 2009, Natuursteen. In: Sportpark Terweide 2. LR41-42: Archeologisch onderzoek Sportpark Terweide (den Hartog, C. M. W.), Basisrapportage Archeologie 18.

Gemeente Utrecht, Utrecht: p. 122-125. (in Dutch) ("Natural stone")

URL: https://www.utrecht.nl/fileadmin/uploads/documenten/wonen-en-leven/vrijetijd/erfgoed/BrA_18_Sportpark_Terweide_2_1_.pdf

Nickel, C. 2011, Die spätkeltisch-frührömische Siedlung auf dem Martberg. Die

Grabungscampagne 2007 und das Fundmaterial der Kampagnen 2006 und 2007 -

Vorbericht. In: Berichte zur Archäologie an Mittelrhein und Mosel 17 (Wegner, H.-H., Ed.), Gesellschaft für Archäologie an Mittelrhein und Mosel and Direktion Landesarchäologie Koblenz, Koblenz: p. 63-266. (in German) ("The Late Celtic - Early Roman settlement on the Martberg. The excavation campaign 2007 and the find material of the campaigns 2006 and 2007 - preliminary report”)

Nieuwhof, A., 2008, Het handgemaakte aardewerk, ijzertijd tot vroege middeleeuwen. In: Opgravingen bij Midlaren 5000 jaar wonen tussen Hondsrug en Hunzedal. Deel 1 (Nicolay, J. A. W., Red.), Groningen Archaeological Studies 7/1. Barkhuis \& University of Groningen, University Library, Groningen: p. 261-304.685-690, pl. 14 (in Dutch) ("The handmade pottery, Iron Age to early Middle Ages")

Nieuwhof, A., \& Niekus, M. J. L. T. 2008, Natursteen. In: De Leege Wier van Englum. Archeologisch onderzoek in het Reitdiepgebied (Nieuwhof, A., Ed.), Jaarverslagen Vereniging voor Terpenonderzoek 91, 2007 (2008). Vereniging voor Terpenonderzoek, Groningen: p. 84-96. (in Dutch) ("Natural stone”)

Oesterwind, B. C. 1997, Aus Ettringens Vorzeit. Heimatbuch Mayen-Koblenz 1998 (1997): 124-132. (in German) ("From the prehistoric past of Ettringen")

URL: http://www.dilibri.de/rlb/periodical/pageview/1210038

Oesterwind, B. C. 2000, Mayen - Zentrum der Mühlsteinherstellung in der Römerzeit. In: Steinbruch und Bergwerk. Denkmäler römischer Technikgeschichte zwischen Eifel und Rhein. Kataloghandbuch zu den Ausstellungen in den Museen von Mayen und Andernach (Bockius, R., Bosinski, G., Hörter, F., Hunold, A., Mangartz, F., Oesterwind, B. C., Schaaff, H., \& Schäfer, K.), Vulkanpark-Forschungen 2. Verlag des Römisch-Germanischen Zentralmuseums, Mainz: p. 33-57, 155-160. (in German) ("Mayen - centre of millstone production in Roman times")

Oesterwind, B. C., \& Schäfer, K. 1985, Eine Siedlung der Spätlatènezeit aus Saffig, Kreis Mayen-Koblenz. Pellenz Museum, 3: 1-16, pl. 1-20. (in German) (“A settlement of the late La Tène period from Saffig, district of Mayen-Koblenz”)

Oesterwind B. C., \& Schäfer, K. 1989, Die Mittellatènezeit im Neuwieder Becken. Pellenz Museum 4. Förderverein Pellenz-Museum e. V., Nickenich, 82 p., 26 pl. (in German) ("The middle La Tène period in the Neuwied basin”)

Oesterwind, B. C., \& Wenzel, S. 2012, Die Entwicklung des Siedlungsgefüges der Eisenzeit zwischen Mayen und Mendig. In: L'âge du Fer entre la Champagne et la vallée du Rhin / Die Eisenzeit zwischen Champagne und Rheintal. 34. Internationales Kolloquium der Association Française pour l'Étude de l'âge du Fer vom 13. bis 16. Mai 2010 in Aschaffenburg (Schönfelder, M., \& Sievers, S., Eds.), RGZM-Tagungen 14. Verlag des Römisch-Germanischen Zentralmuseums, Mainz: p. 337-363. (in German) (“The development of Iron Age settlement structures near Mayen and Mendig”)

Pause, C. 2015, Mühlstein, 1. Jahrhundert n. Chr. In: Clemens Sels Museum Neuss. Meisterwerke der Sammlung. Große Kunst im kleinen Format (Husmeier-Schirlitz, U., 
Ed.), Clemens-Sels-Museum, Neuss: p. 158-159. (in German) (“Quern. 1st century AD”)

Peacock, D. 2013, The Stone of Life. The Archaeology of Querns, Mills and Flour Production in Europe up to c. AD 500. Southampton Monographs in Archaeology New Series 1. The Highfield Press Southampton, Southampton, 220 p.

Picavet P., Fronteau, G., \& Boyer, F., 2011, Les meules romaines de sept chefs-lieux de cité de Gaule Belgique occidentale, étude du matériel et synthèse bibliographique. Revue du Nord, 93(393): 167-226. (in French) (“The Roman mills from seven civitas capitals in the west of Gallia Belgica, material study and bibliographic synthesis”) doi:10.3917/rdn.393.0167

van Pruissen, C., \& Kars, E. A. K., 2009, Natuursteen. In: Opgravingen in GeldermalsenHondsgemet, een inheemse nederzetting uit de Late IJzertijd en de Romeinse tijd (van Renswoude, J., \& van Kerckhove, J., Eds.), Zuidnederlandse Archeologische Rapporten 35. Archeologisch Centrum Vrije Universiteit, Amsterdam 2009: p. 303-318 (in Dutch) ("Natural stone")

Rees, S. 2011, Agriculture. In: Artefacts in Roman Britain: Their purpose and use (AllasonJones, L., Ed.), Cambridge University Press, Cambridge: p. 89-113.

Reniere, S., De Clercq, W., Dreesen, R., Goemaere, E., Fronteau, G., Gluhak, T., Hartoch, E., \& Picavet, P. 2016, Querns and mills during Roman times at the northern frontier of the Roman Empire (Belgium, Northern France, Southern Netherlands, Western Germany): Unraveling geological and geographical provenances, a multidisciplinary research project. Journal of Lithic Studies, 3(3), 403-428. doi:10.2218/jls.v3i3.1640

Roymans, N., \& Aarts, J. 2009, Coin use in a dynamic frontier region. Late Iron Age coinages in the Lower Rhine area. Journal of Archaeology in the Low Countries 1-1, (May 2009): 5-26. URL: http://jalc.nl/cgi/t/text/get-pdf86de.pdf?c=jalc;idno=0101a02

Salač, V. 2006, O obchodu v pravěku a době laténské především. On trade in prehistory, and especially in the La Tène. Archeologické rozhledy, 58: 33-58. (in Czech, with English summary) URL: http://www.arup.cas.cz/wp-content/uploads/2010/05/ObchodAR.pdf

van der Sanden, W. A. B. 1998, Zware gaven: maalstenen uit natte context in Drenthe. Nieuwe Drentse Volksalmanak, 115: 107-130. (in Dutch) ("Heavy gifts: grinding stones from a wet environment in Drenthe")

Schaaff, H. 2010, Steine für das römische Reich. Zu den Anfängen des antiken Steinbruchund Bergwerksreviers zwischen Eifel und Rhein. Archäologisches Korrespondenzblatt, 40(2): 265-272. (in German) ("Stones for the Roman Empire - on the beginnings of the ancient quarrying and mining district between Eifel area and Rhine”)

Schäfer, K. 2000, Andernach - Drehscheibe des antiken Steinhandels. In: Steinbruch und Bergwerk. Denkmäler römischer Technikgeschichte zwischen Eifel und Rhein. Kataloghandbuch zu den Ausstellungen in den Museen von mayen und Andernach (Bockius, R., Bosinski, G., Hörter, F., Hunold, A., Mangartz, F., Oesterwind, B.C., Schaaff. H., Schäfer, K.), Vulkanpark-Forschungen 2. Verlag des RömischGermanischen Zentralmuseums, Mainz: p. 83-109, 155-160. (in German) (“Andernach hub of the ancient stone trade")

Schinkel, K., 1998, Unsettled settlement, occupation remains from the Bronze Age and the Iron Age at Oss-Ussen. The 1976-1986 excavations. In: The Ussen project: the first decade of excavations at Oss (Fokkens, H., Ed.), Analecta Praehistorica Leidensia 30. 
Leiden University, Leiden: p. 5-305.

URL: https://openaccess.leidenuniv.nl/handle/1887/33828

Schönberger, H. 1961, Ein augusteisches Lager in Rödgen bei Bad Nauheim. Saalburg Jahrbuch, 19: 37-58, supplements 4-5. (in German) (“An Augustan camp in Rödgen near Bad Nauheim”)

Schulze-Forster, J. 2010: Kelten, Germanen, Ubier, Chatten? Zur ethnischen und historischen Deutung spätlatènezeitlicher Fundgruppen in Hessen. Berichte der Kommission für Archäologische Landesforschung in Hessen, 10, 2008/2009 (2010): 17-26. (in German) ("Celts, Germanic people, Ubii, Chatti? On the ethnic and historical interpretation of Late La Tène finds in Hesse”)

Schwarz, P.-A. 2004, Die prähistorischen Siedlungsreste und die frühkaiserzeitlichen Holzbauten auf dem Kastelenplateau, Forschungen in Augst 21. Römermuseum Augst, Augst, 400 p. (in German) ("The prehistoric settlement remains and the early imperial wooden buildings on the Kastelenplateau")

URL: http://www.augustaraurica.ch/fileadmin/user_upload/2_Arch\%C3\%A4ologie/7_L iteratur\%20und\%20Verlag/02_Forschungen_in_Augst/FiA21.pdf

Shaffrey, R. 2010, The other worked stone. In: The Carlisle Millennium Project: Excavations in Carlisle, 1998-2001. Volume 2: The finds (Howard-Davis, C.). Lancaster Imprints 15, Oxford Archaeology North, Lancaster, UK: p. 873-887.

Shaffrey, R. 2011: Worked stone. In: Settling the Ebbsfleet Valley. High Speed 1 excavations at Springhead and Northfleet, Kent. The Late Iron Age, Roman, Saxon, and Medieval landscape. Volume 2: Late Iron Age to Roman finds reports (Biddulph, E., Seager Smith, R., \& Schuster, J.), Wessex Archaeology, Oxford and Salisbury: p. 363-377, 405-420.

Shaffrey, R. 2015, Intensive milling practices in the Romano-British landscape of Southern England: Using newly established criteria for distinguishing millstones from rotary querns. Britannia, 46: 55-92. doi:10.1017/S0068113X15000185

Simon, H.-G. 1961, Die Funde aus dem Bereich des Lagers in Rödgen. Saalburg Jahrbuch, 19: 59-88. (in German) ("The finds from the area of the camp in Rödgen”)

Simons, A. 1987, Archäologischer Nachweis eisenzeitlichen Salzhandels von der Nordseeküste ins Rheinland. Archäologische Informationen, 10(1): 8-14. (in German) ("Archaeological evidence of Iron Age salt trade from the North Sea coast to the Rhineland”) doi:10.11588/ai.1987.1.26926

Staubitz, H.-J. 2007, Die Mühlsteine des spätkeltischen Heidetränk-Oppidums im Taunus, Kleine Schriften aus dem Vorgeschichtlichen Seminar Marburg 56. Vorgeschichtliches Seminar der Philipps-Universität Marburg, Marburg, 72 p. (in German) (“The querns of the late celtic Heidetränk-Oppidum in the Taunus”) URL: http://archiv.ub.unimarburg.de/eb/2015/0214/view.html

Stümpel, B. 1991, Beiträge zur Latènezeit im Mainzer Becken VI. Funde der jüngeren Latènezeit im Gau-Odernheimer Raum. In: Beiträge zur Latènezeit im Mainzer Becken und Umgebung (Stümpel, B.), Beihefte der Mainzer Zeitschrift 1. Verlag des Mainzer Alterumsvereins, Mainz: p. 37-41. (in German) ("Contributions to the La Tène period in the Mainz basin VI. Finds of the younger La Tène period in the area of GauOdernheim”) 
Taayke, E., Peen, C., van der Harst-Domburg, M., \& Vos, W. 2012, Ede vol Erven. Germaanse bewoning op de rand van een wereldrijk (500 BC - 500 AD). Hazenberg Archeologie, Leiden, 369 p. (in Dutch) ("Ede full of heritage. Germanic occupation on the edge of a world empire (500 BC - $500 \mathrm{AD}$ )”)

Trebsche, P. 2013, Neue Mühlen mahlen schneller - Landwirtschaftliche Techniken in der Eisenzeit. In: Brot \& Wein [Volume 1: Brot] (Etzlsdorfer, H., Pfaffenbichler, M., Rapp, Ch., \& Regner, F., Eds.), Niederösterreichische Landesausstellung 2013 (Schallaburg 2013) p. 93-99. (in German) ("New querns grind faster - agricultural techniques in the Iron Age")

URL: http://homepage.univie.ac.at/peter.trebsche/Trebsche_2013,\%20Neue\%20Muehle n\%20mahlen\%20schneller.pdf

Tremmel, B. 2011, Augusteische Marschlager in Porta Westfalica-Barkhausen „Auf der Lake“. Archäologie in Westfalen-Lippe, 2010 (2011): 79-81. doi:10.11588/aiw.0.0.25926

Van Ossel, P., \& Defgnée, A. 2001, Champion, Hamois. Une villa romaine chez les Condruses. Archeologie, environnement et economie d'une exploitation agricole antique de la Moyenne Belgique. Etudes et Documents, Archéologie 7. Ministère de la Région wallone, Namur, 280 p. (in French) ("Champion, Hamois. A Roman villa at the Condruses")

de Vries, K. M. 2015, Together apart. Iron Age deposition practices on the Fries-Drents plateau. Research Master thesis, University of Groningen, Groningen, 128 p. URL: http://arts.studenttheses.ub.rug.nl/16577/1/Ma-1615017-K.M._de_Vries_.pdf

Waterbolk, H. T. 1977, Walled enclosures of the Iron Age in the North of the Netherlands. Palaeohistoria, 19: 97-172. URL: http://rjh.ub.rug.nl/Palaeohistoria/article/view/25020

Wefers, S. 2006, Ein latènezeitlicher (?) Drehmühlensteinbruch im Stadtwald von Borken (Schwalm-Eder-Kreis). Archäologisches Korrespondenzblatt, 36(1): 65-74. (In German) ("A Late Iron Age (?) rotary quern quarry in the Stadtwald of Borken (Schwalm-Eder-Kreis”)

Wefers, S. 2011, Still using your saddle quern? A compilation of the oldest known rotary querns in western Europe. In: Bread for the People: Archaeology of Mills and Milling. Proceedings of a Colloquium Held in the British School at Rome, 4th-7th November 2009 (Williams, D., \& Peacock, D., Eds.), BAR International Series 2274. Series in Archaeology 3, Archaeopress, Oxford, p. 67-76.

Wefers, S. 2012a, Latènezeitliche Mühlen aus dem Gebiet zwischen den Steinbruchrevieren Mayen und Lovosice, Monographien RGZM 95, Vulkanpark-Forschungen 9. Verlag des Römisch-Germanischen Zentralmuseums, Mainz, xii, 359 p., 142 pl. (in German) ("Querns of the La Tène period from the area between the quarry districts of Mayen and Lovosice”)

Wefers, S. 2012b, Die Funde von Drehmühlen im Lager 1 von Hedemünden. In: Römerlager Hedemünden. Der augusteische Stützpunkt, seine Außenanlagen, seine Funde und Befunde (Grote, K., Ed.), Veröffentlichungen der archäologischen Sammlungen des Landesmuseums Hannover 53. Sandstein-Verlag, Dresden: p. 231-234, 319-338, pl. 6365.93. (in German) ("Finds of rotary querns in fort 1 of Hedemünden”) 
Wefers, S., \& Gluhak, T. 2010, Eifel lava - the provenance of two Late Iron Age rotary querns discovered in Bohemia. Archeologické rozhledy, 62(1): 3-16. URL: http://www.arup.cas.cz/wp-content/uploads/2010/11/AR_2010-01.pdf

Wenzel, S. 2012, Villa und burgus von Obermendig »Im Winkel« (Lkr. Mayen-Koblenz) im Kontext der römischen Besiedlung des Segbachtals. In: Römische Landnutzung in der Eifel - Neue Ausgrabungen und Forschungen (Grünewald, M., \& Wenzel, St., Eds.), RGZM - Tagungen 16, Verlag des Römisch-Germanischen Zentralmuseums, Mainz, p. 131-158. (in German) ("Villa and burgus of Obermendig »Im Winkel « (district of Mayen-Koblenz) in the context of the Roman settlement of the Segbachtal”)

Wesselingh, D. A. 2000, Native Neighbours: local settlement system and social structure in the Roman period at Oss (The Netherlands), Analecta Praehistorica Leidensia 32. Leiden University, Leiden, 254 p. URL: http://hdl.handle.net/1887/33738

Wiegert, M. 2002, Der Hunnenring von Otzenhausen, Lkr. St. Wendel. Die Siedlungsfunde und Bebauungsstrukturen einer spätlatènezeitlichen Höhenbefestigung im Saarland, Internationale Archäologie 65. Leidorf, Rahden in Westfalen, 674 p. (in German) ("The Hunnenring of Otzenhausen, district of St. Wendel. The settlement finds and building structures of a late La Tène hill fort in the Saarland”)

Wilhelmi, K. 1973, Eine Siedlung der vorrömischen Eisenzeit bei Sünninghausen, Kr. Beckum, Bodenaltertümer Westfalens, 13: 77-137. (in German) ("A settlement of the pre-Roman Iron Age at Sünninghausen, district of Beckum”)

Williams, D., \& Peacock, D. P. S. 2011, The quernstone assemblage. In: Roman London and the Walbrook stream crossing. Excavations at 1 Poultry and vicinity, City of London, part 2 (Hill, J., \& Rowsome, P., Eds.), MOLA Monograph 37. Museum of London Archaeology, London: p. 452-457, 571-587.

Wootton, W., Russell, B., \& Rockwell, P. 2013, Stoneworking tools and toolmarks (version 1.0), The Art of Making in Antiquity: Stoneworking in the Roman World. King's College, London, 27 p. Accessed: 14 December 2017.

URL: http://www.artofmaking.ac.uk/content/essays/2-stoneworking-tools-andtoolmarks-w-wootton-b-russell-p-rockwell/

Zant, J. 2016, Excavations on a Roman salt-working site at Jersey Way, Middlewich, Cheshire. With contributions by D. Druce, R. A. Gregory, Chr. Howard-Davis, R. Leary, M. Rutherford, D. Shotter, I. Smith, I. Tyers and M. Ward. Archaeological Journal, 173(1): 56-153. doi:10.1080/00665983.2015.1119637

Zeeb-Lanz, A. 2008, Der Donnersberg. Eine bedeutende spätkeltische Stadtanlage, Archäologische Denkmäler in der Pfalz 2. GDKE, Direktion Landesarchäologie, Außenstelle Speyer, Speyer: 78 p. (in German) ("The Donnersberg. An important late Celtic town”) 


\section{Supplementary material}

\section{Appendix 1. List of findspots}

For some localities only selected finds are listed. Also, in respect to the information on the querns a selection was made. For further dimensions and a more detailed description, please refer to the literature. Specifications of the material are quoted verbatim.

Abbreviations: $\approx$ - approximately; b. - breadth; cat. no. - catalogue number; diam. diameter; find no. - find number; GDKE - Generaldirektion Kulturelles Erbe; h. - height (= thickness); inv. no. - Inventory number; l. - length; max. - maximal; min. - minimal; RLMB Rheinisches Landesmuseum Bonn.

1 - Arnhem-Schuytgraaf (province of Gelderland; the Netherlands). (Melkert 2015: 328 note 649)

2 - Augst (canton of Basel-Landschaft; Switzerland), Kastelenplateau, insula 2 (south) (phase 1.4; before 60/70 CE). Catillus (fragment, about an eighth), diam. $\approx 44 \mathrm{~cm}$ (Schwarz 2004: 176.313, fig. 128:428)

3 - Avenches (canton of Vaud, Switzerland); northeast quarter of the Roman town; feature of 150-200/250 CE. Meta, diam. 34,0 cm, h. at margin 5,5 cm; side face vertical, unterside concave hollowed out; "basalte”. [Musée romain d'Avenches, 93/9289-5]. (Castella \& Anderson 2004: 122, pl. 3:64).

4 - Bad Lippspringe (district of Paderborn, Germany), "Hoher Kamp”; found after deep ploughing. Meta; diam. 33,6 cm; with convexe grinding surface and oval central perforation ( $\approx 6,3 \times 4,2 \mathrm{~cm})$; "Basaltlava". (Günther 1983: 265, fig. 73:2).

5 - Bad Nauheim (Wetteraukreis, Germany). - 1 "Lattkaute” (celtic southern settlement): Catillus, diam. 35,0 cm; h. at margin 11,0 - 12,0 cm; eye oval $(5,4 \mathrm{~cm} \times 5,0 \mathrm{~cm})$ with polished sides, funnel-shaped to the top; upper face and grinding surface roughly pecked; "phonolitischer Tephrit (Gruppe 1)". (Wefers 2012a: 222, pl. 10:47). - 2 Probably "Lattkaute": Meta, diam. 35,0 cm; waist highly polished; hole for spindle round and through (diam. 3,6 cm); grinding surface with pecking marks; underside roughly worked; “phonolitischer Tephrit (Gruppe 1)”. (Wefers 2012a: 223, pl. 11:49).

6 - Barkhausen, town of Porta Westfalica (district of Minden-Lübbecke, Germany); marching camp dating from the Late Augustan period (time of Christ's birth to 9/16 CE). Catillus (Barkhausen 1), diam. ?, h. at margin $\approx 7,8 \mathrm{~cm}$, "Basaltlava aus dem Mayener Grubenfeld”. [Archaeological find archive of LWL-Archäologie für Westfalen, inv. no. BaHa F47] (Gluhak 2010: 281; Schaaff 2010: 267, note 37 (p. 271), fig. 2:3; Tremmel 2011).

7 - Bavay (département Nord; France). Catillus, diam. $39 \mathrm{~cm}$, pitch-angle $9^{\circ}$, tooling in segments, clockwise; "roche volcanique". [Forum antique de Bavay, musée archéologique du département du Nord, no. 81 A 28 = 73 Z 1053]. (Picavet et al. 2011: 169 (date), 221 no. 66, fig. 41:66).

8 - Biebertal-Fellinghausen (district of Gießen, Germany), oppidum Dünsberg. Meta, diam. 30.5 - $31.5 \mathrm{~cm}$; grinding surface with sharpening groves near the margin; hole for spindle oval and through $(1.3 .8 \mathrm{~cm}$, b. $3.5 \mathrm{~cm})$, widened funnel-shaped downwards; underside roughly pecked; lateral face tapers towards the bottom; "phonolithischer Tephrit? (Gruppe 1); Bestimmung rein makroskopisch ...”. [Museum Wiesbaden, inv. no. 13,77] (Wefers 2012a: 231, pl. 16:88). 
9 - Bierfeld, municipiality of Nonnweiler (district of St. Wendel, Germany); "Vor dem Erker”, grave 1/2013 (La Tène D2b, ca. 50-20 BCE): 1 Catillus (46 fragments, more than three quarters present) with concave upper side and underside; straight lateral face; diam. $38 \mathrm{~cm}$; very thin in the area of the eye (diam. of eye $5 \mathrm{~cm}$ ), perforation for handle on lateral face; weight $\approx 14 \mathrm{~kg}$. - 2 Meta with concave underside (25 large fragments and 23 splinters; almost complete); diam. $37 \mathrm{~cm}$; hole for spindle (diam. $4 \mathrm{~cm}$ ); weight 17.5 kg; "Basaltlava”. (Gleser \& Fritsch 2014: 162, fig. 12.18).

10 - Bolland near Lions (Leons), municipality of Littenseradiel (province of Friesland, the Netherlands), pit with pottery of ca. 50 CE. Catillus and perhaps meta, "tefriet". (De Langen et al. 1994: 74-79).

11- Briedel (district of Cochem-Zell, Germany), "Briedeler Heck". - 1 Barrow cemetery A, tumulus A 9, spot 4: Catillus, diam. $\approx 40 \mathrm{~cm}$, "Mayener Basaltlava". [RLMB 37.434ap]. (Joachim 1982b: 74.92, pl. 8:24). - 2 Barrow cemetery B, tumulus 3: Meta; diam. 36 $\mathrm{cm}$; radial groves on margin of grinding surface; "Mayener Basaltlava". [RLMB 37.455a-d]. (Joachim 1982b: 77.92.106, pl. 22:11).

12 - Brillerij, municipality of Winsum (province of Groningen, the Netherlands); terp excavation 1910. Matching and still usable pair of upper and lower stones: Catillus with biconcave cross-section, diam. of grinding surface $36.5-37 \mathrm{~cm}$; on the top slight concentric picking marks; grinding face abraded by use; h. at margin $7.8-9.2 \mathrm{~cm}$; cylindrical eye (diam. 4 cm, h. $2 \mathrm{~cm}$ ); elbow-shaped perforation for handle extends from the lateral face to the upper side, mouths clearly polished; "basaltlava”. Meta with domed grinding surface and irregular concave underside; diam. $32.5-34 \mathrm{~cm}$; h. at margin 3.8 - $6 \mathrm{~cm}$; hole for spindle (diam. $3.5 \mathrm{~cm}$ ) widens continuously downwards; “basaltlava”. [Groninger Museum; inv. no. catillus 1910/I/264a, meta 1910/I/264] (Harsema 1967: fig. 5:1.1a; van Heeringen 1985: 379, GR 2)

13 - Buinen, municpiality of Borger-Odoorn (province of Drenthe, Netherlands); found on field. Meta (half, 31.5 x $18 \mathrm{~cm}$ ), diam. 32 cm, max. h. 5.5 cm, min. h. 3.5 cm, "basalt”like lava according to photo. (Hopman 2010: supplement 1, 1989-VI.7).

14 - Creil (département Oise, France), "Les Cerisiers”, settlement (La Tène III). Meta, diam. $28 \mathrm{~cm}$, with domed grinding surface and concave hollowed out bottom, hole for spindle broken; "une pierre d'importation (basalte bulleux) dont le seul gisement connu est situé à "Maar", Eifel-Daun (R.F.A.) près du Rhin”. (Fémolant 1989: 62, fig. 28:1).

15 - Cugnon (Province de Luxembourg, Belgium), oppidum of "Trînchi”. Lower stone, diam. 35,8 cm, "lave basaltique de l'Eifel” (Matthys \& Hossey 1979: 18, fig.14:5; Hartoch et al. 2015, 178).

16 - Daaden (district of Altenkirchen, Germany), “Kleines Steinchen”. Meta; diam. originally 38.0 - $37.0 \mathrm{~cm}$; domed grinding surface, with grooves in clockwise direction; hole for spindle round and through (diam. 2.7 - $3.0 \mathrm{~cm}$ ); underside concave; lateral face tapers towards the bottom; “phonolitischer Tephrit (Gruppe 1)”. (Wefers 2012a: 244-245, pl. 28:157). 
17 - Dannenfels (Donnersbergkreis, Germany), oppidum Donnersberg. 1 Catillus (fragment) with concave upper side and concave grinding surface; in the lateral face horizontal hole for handle, "Eifelbasalt”. (Zeeb-Lanz 2008: fig. 49 right; photo documentation by Klaus Mages, email from 15.09.2017). - 2 Find spot 17, middle rampart, profile A-B, found digging (mechanically): Meta (slightly less than half, L. $34.5 \mathrm{~cm}, \mathrm{~B} 17.5 \mathrm{~cm}$ ), diam. at top $36 \mathrm{~cm}$; diam. at bottom $34 \mathrm{~cm}$; h. $9.7 \mathrm{~cm}$; h. at margin $6.5-7 \mathrm{~cm}$; perforation for spindle through (diam. $\approx 5.2 \mathrm{~cm}$ ); fine-pored "basalt"-like lava with inclusions of pyroxene and quartz. [GDKE Rheinland-Pfalz, Landesarchäologie Speyer; E.-Nr. 2009/0102]. - 3 Find spot 17 (7.2.07): Meta (2 fragments, together less than half), slightly out of round, diam. $34-32 \mathrm{~cm}$; h. at margin $10.1-8.6 \mathrm{~cm}$; hole for spindle through (diam. $\approx 2.7 \mathrm{~cm}$ ); lateral face tapers towards the bottom; on the lateral surface and on the grinding surface no working traces visible; on the underside indistinct negatives of chipping; coarse-pored "basalt"-like lava with augite. [GDKE RheinlandPfalz, Landesarchäologie Speyer; E.-Nr. 2006/0105; carton no. 38298].

18 - De Palen, municipality of Loppersum (province of Groningen, the Netherlands); settlement De Palen I, 7Bn15 (1970/III 1). Catillus, diam. 36-38 cm, "basaltlava ... uit het Midden Rijngebied”. (Miedema 2002: 325, fig. 179:1).

19 - Dietenhausen-Atzbach (district of Limburg-Weilburg, Germany), “Atzbach”. Catillus, diam. originally $37.5 \mathrm{~cm}$; upper side with pecking marks; grinding surface with sharpening grooves; margin of eye crumbled; and meta, diam. originally 34.5 - $35.5 \mathrm{~cm}$; grinding surface with pecking marks, obliquely abraded; hole for spindle oval and through (l. $4.8 \mathrm{~cm}$, b. $4.5 \mathrm{~cm}, \mathrm{~d} .2,3 \mathrm{~cm})$, underside roughly pecked; lateral face tapers towards the bottom; both "phonolithischer Tephrit? (Gruppe 1); Bestimmung rein makroskopisch ...”. [Bergbau und Stadtmuseum Weilburg, inv. no. 36-38/2289 a-b] (Wefers 2012a: 245-246, pl. 29:160.161).

20 - Dornburg-Wilsenroth (district of Limburg-Weilburg, Germany), Dornburg. 1 Catillus (fragment, 17-16.9 cm); original dm. $37 \mathrm{~cm}$; h. at margin $10.9 \mathrm{~cm}$; cross section biconcave; grinding surface with picking marks; "phonolithischer Tephrit? (Gruppe 1); Bestimmung rein makroskopisch ...”. [Dorfmuseum Wilsenroth, Inv.-No. -] (Wefers 2012a: 247, pl. 30:166). - Meta; diam. 33 - 33.8 cm; h. at margin 5.1 - $6.6 \mathrm{~cm}$; grinding surface domed and with picking marks; hole for spindle round and through, widened funnel-shaped downwards (diam. 4.1 - $4.4 \mathrm{~cm}, 1.1 .5$ - $2 \mathrm{~cm}$ ); underside concave; lateral face tapers towards the bottom; weight $9.5 \mathrm{~kg}$; "phonolithischer Tephrit? (Gruppe 1); Bestimmung rein makroskopisch ...”. [Dorfmuseum Wilsenroth, inv. no. 49/15] (Wefers 2012a: 248, pl. 31:171).

21 - Englum, municipality of Zuidhorn (province of Groningen, the Netherlands), Leege Wier (Englum I). Catillus (two fragments; not complete); diam. 35.5 - $37 \mathrm{~cm}$; h. at margin 8 $\mathrm{cm}$; (elbow-shaped ?) perforation on upper side, margin of eye crumbled, "basaltlava" (Eifel). [Find no. 160] (Nieuwhof \& Niekus 2008: 90 table 6.5, fig. 6.3).

22 - Eschweiler-Laurenzberg (district of Düren, Germany); settlement of the late Iron Age. 1 spot 445: Catillus (fragments, about one third), diam. $37.6 \mathrm{~cm}$; "Basaltlava”. (Joachim 1980: 402, fig. 25:2, Hörter 2000: fig. 2, 2). 2 spot 527, shovel planum: Catillus (fragment, about a quarter), diam. 34.3 cm, "Basaltlava". (Joachim 1980: 402, fig. 27:4). - 3 building 43, spot 355: Meta (fragments, about half), Dm. $35.5 \mathrm{~cm}$; “Basaltlava”. (Joachim 1980: 384, fig. 16:4). - 4 building 43, spot 355: Meta (fragments, together about half), diam. 35 cm; "Basalt”. (Joachim 1980: 384, fig. 17:4, Hörter 2000: fig. 2:2). [All finds of the settlement: RLMB 74.4332-74.4737, 74.91174.4916] (Joachim 1980: 357 note 8). 
23 - Eschweiler-Lohn (district of Düren, Germany); settlement of the late Iron Age, planum 2, spot 113. Meta, diam. 31.5 cm; "Basalt”. (Joachim 1980: 434, fig. 46:5; Hörter 2000: fig. 2:2). [All excavated finds from the settlement: RLMB 74.4738-74.910] (Joachim 1980: 358 note 11$)$.

24 - Ettringen (district of Mayen-Koblenz, Germany), Nachtigallenweg, grave 3 (3rd quarter of the 1st century CE). Meta (four fragments), diam. 37.5-38 cm, h. 8-9 cm; grinding surface domed, with sharpening grooves; and catillus (two fragments), h. $11 \mathrm{~cm}$, with biconcave section and sharpening grooves on the underside; all outer sides left rough; lateral face with round perforation for handle (diam. $3.5 \mathrm{~cm}, 5 \mathrm{~cm}$ deep), with angled exit to the top (diam. $2 \mathrm{~cm}$ ), "Basaltlava”. [Eifelmuseum Mayen]. (Oesterwind 1997: 129, fig. 6).

25 - Geldermalsen-Hondsgement (province of Gelderland, the Netherlands). Catillus; diam. $33 \mathrm{~cm}$; h. at margin $9 \mathrm{~cm}$, eye of irregular shape (diam. $5 \mathrm{~cm}$ ); two holes as handle sockets, one of which has been abraded by use; weight: $10.966 \mathrm{~kg}$; "tefriet". [find no. V121.137]. (Van Pruissen \& Kars 2009: 311-312, fig. 10.9; Melkert 2015: 328 note 649).

26 - Groesbeek, municipality Berg en Dal (province of Gelderland, the Netherlands), "Lage Wald" near the border to Wijler (Wyler); found during tillage. Catillus, diam. 40 - 42 $\mathrm{cm}$, diam. eye ?, on the lateral face two holes for the handle (round, diam. $4 \mathrm{~cm}$, depth 4 $\mathrm{cm}$, slightly tapered, surface smooth; square, sides $4 \mathrm{~cm}$, depth $3.7 \mathrm{~cm}$, surface rough); “tephriet ("bazaltlava”)”. (Hulst 1987: 213, fig. 4).

27 - Haaksbergen (province of Overijssel, the Netherlands), Haaksberg veen. In 1875 and circa 1933, a total of three pairs of upper and lower stones were found; "basalt lava". One of the runners found in 1875 still had a leather strap and a wooden stake in the hole on the side. (van Es \& Verlinde 1977: 76, 79 no. 23, fig. 75; van Heeringen 1985: 380 OV 2; van Beek 2009: 515-516, fig. 15.3).

28 - Halfweg, Gem. Vries (province of Noord-Holland, the Netherlands). Catillus, "basaltlava”. [Drents museum, 1935/11, 13]. (Harsema 1979: fig. 6, 1; van Heeringen 1985: 379, DR 2).

29 - Hamois, Emptinne (Belgium); axial villa "Champion”, "Le Rosdia”, pit F 18.3. 1 Catillus, diam. $\approx 34 \mathrm{~cm}$, "lave basaltique". (van Ossel \& Defgnée 2001: 165-166, fig. 145:5). - 2 Meta (fragment), with flat radial grooves on the slightly domed grinding surface, h. at margin 4 cm, "lave basaltique”. (van Ossel \& Defgnée 2001: 165, fig. 145:3).

30 - Heddernheim, city district of Frankfurt am Main (Germany). Catillus (fragment, 34 x 17 $\mathrm{cm})$, diam. originally $36 \mathrm{~cm}$; cross-section biconcave; eye oval $(1.8 \mathrm{~cm}$, b. 5,5 cm), widens out funnel-shaped 2 cm upwards; "phonolitischer Tephrit (Gruppe 1)". [Archäologisches Museum Frankfurt am Main, inv. no. 1987.53.390]. (Wefers 2012a: 251, pl. 33:182)

31 - Hedemünden, municipality of Hannoversch Münden (district of Göttingen, Germany), "Sudholz"; Roman fort 1 (Augustan). Meta; diam. $\approx 30-31.4 \mathrm{~cm}$, diameter reduced secondarily? hole for spindle through (diam. $\approx 5.4 \mathrm{~cm}$ ); four secondary holes in the grinding surface; “phonolitischer Tephrit”. (Wefers 2012b: 232-233, pl. 63).

32 - Hermeskeil (Trier-Saarburg district, Germany). Catillus, diam. $38 \mathrm{~cm}$, diam. of eye 6-8 $\mathrm{cm}$, h. at margin $\approx 14 \mathrm{~cm}$. (Hornung 2016: 152, fig. 130:1). 
33 - Hommertshausen, municipality of Dauphetal (Marburg-Biedenkopf district, Germany), ringfort "Eisenköpfe”, on a leveled dwelling area ('podium'). Catillus (fragment, about a third); diam. originally $\approx 38 \mathrm{~cm}$; upper surface concave with pecking marks; grinding surface concave with radial grooving; eye round (?) (diam. $4 \mathrm{~cm}$ ), h. at margin 12.1 $12.2 \mathrm{~cm}$; lateral face straight, "phonolitischer Tephrit (Gruppe 1)”. (Wefers 2012a: 261, pl. 41:216).

34 - Houten-Castellum (province of Utrecht, the Netherlands), channel filling of the middle Roman period (together with saddle quern of lava, V22.147-1): Catillus, "bi-concaaf", diam. 30 cm, h. max. 9 cm, h. min. 4 cm, “tefriet”. [Find no. V24.156]. Boreel 2017, 593, Tabel 12.12.

35 - Houten (province of Utrecht; the Netherlands), Schalkwijkseweg, terrain 14; settlement of the Iron Age and the Roman period: Half of meta, diam. $35 \mathrm{~cm}$, h. max. $10 \mathrm{~cm}$, diam. of hole for spindle 3,7 cm, “tefriet”. [Find no. 226/1]. Niekus in Krist et al. 2001: 105, fig. 10.1.

36 - Inden-Altdorf (district of Düren, Germany); supposed watermill. Three lower stones, diam. 29-36 cm; fragment of an upper stone of double concave cross section. (Geilenbrügge \& Schürmann 2010: fig. 69; Fuchshofen \& Geilenbrügge 2010: 96, fig. 2, WW 128 area C).

37 - Kerkenveld (province of Drenthe; the Netherlands); found 1962 digging in front garden, on sand under $0.75 \mathrm{~cm}$ of peat. Pair of upper and lower stone: Catillus; diam. $37.2 \mathrm{~cm}$, h. 9,8 cm; diam. of eye $3 \mathrm{~cm}$; top and bottom are virtually flat; "tefriet". Meta, diam. $37.5 \mathrm{~cm}$; h. 10,1 cm; diam. of hole for spindle $3.9 \mathrm{~cm}$; "tefriet". [Drents Museum, 1962/VII 3a-b] (van der Sanden 1998, 120 no. 10; de Vries 2015: 109 Kerk).

38 - Königswinter (Rhein-Sieg-Kreis; Germany); hillfort on Petersberg; section 16, lowermost stone layer of the rampart. Catillus (3 fragments), diam. $33.5 \mathrm{~cm}$, h. at margin 9 cm; "Mayener Basaltlava” [RLMB 38.1338/178] (Joachim 1982a, 409, fig. 15, 3).

39 - Kottenheim (district of Mayen-Koblenz, Germany; “Im Hengst”. 1 pit 3: Roughout for meta, diam. at top $31.5 \mathrm{~cm}$, diam. at base $26.5 \mathrm{~cm}$, h. at margin $16-16.5 \mathrm{~cm}$; fine pored vesicular lava. [RLMB 39.1200c] - 2 pit 5: Roughout for meta, diameter at top $38.2 \mathrm{~cm}$, diam. at base $33 \mathrm{~cm}$, h. at margin 13-13.5 cm; hole for spindle through, borings from top (diam. 5.5-5.6 cm) and base (diam. 4.5-4.6 cm) slightly misplaced; mostly fine pored vesicular lava. [RLMB 39.1201f].

40 - Lierop-Boomen, municipality of Sommeren (province of Noord-Brabant; the Netherlands), Laan ten Boomen 31; found in 1880 during the construction of a stable. Catillus, diam. $36-37 \mathrm{~cm}$, h. $9.7 \mathrm{~cm}$; diam. of eye $8.5-11.3 \mathrm{~cm}$; elbow-shaped perforation for handle; “tefriet (basaltlava)”. (Kortlang 2011: 53, fig. 13).

41 - Löhne-Mennighüffen (district of Detmold, Germany), gravel pit in oxbow of the Werre, near house Gohfeld. Catillus, diam. $37 \mathrm{~cm}$, with elbow-shaped perforation, and meta, diam. at top 35,4 cm, diam. at base $33 \mathrm{~cm}$; "Basaltlava" from "Niedermendig bei Mayen”. (Bérenger 1983: 236-237, fig. 50).

42 - Maasland, Foppenpolder (province of Zuid-Holland, the Netherlands), settlement MD 15.04 (turn of the 3rd / 2nd century BCE). Fragments of a Brillerij type quern, and of a saddle quern (Napoleon's hat); both of “tefriet”. (van den Broeke \& van Londen 1995: fig. on p. 33 (schematic drawings); Lanting \& van der Plicht 2006: 330.359; Hartoch et al. 2015, 178). 
43 - Mayen (district of Mayen-Koblenz, Germany); Brückenstraße 30, found 1928 behind the house of Mr. Cossmann. Catillus; diam. 36.2 -36.4 cm; upper surface with pecking marks; underside with slightly polished radial sharpening grooves; eye (diam. $4 \mathrm{~cm}$ ) with polished margin; lateral face straight, there elbow-shaped perforation for handle (mouth round, diam. $4.5 \mathrm{~cm}$ ), which extends to the upper side (mouth drop-shaped, 1. 2.7, b. $1.5 \mathrm{~cm}$ ); Mayen lava. [Museum Hachenburg, inv. no. 1831] (Mangartz 2008: 238 no. 1-36b, fig. 123; Wefers 2012a: 328 no. 548, pl. 102:548).

44 - Mayen (district of Mayen-Koblenz, Germany); Mayen or surroundings, probably from the quarry district of Mayen. Failed roughout for catillus, basic shape cylindrical, diam. at top $35.8 \mathrm{~cm}$, diam. at base $37.0 \mathrm{~cm}$; h. $18.8-17.8 \mathrm{~cm}$; upper surface concave, surface with pecking marks, in the middle unfinished eye $($ diam. $\approx 4.0 \mathrm{~cm}$, depth $\approx 5.5 \mathrm{~cm}$, not through); lateral face with longish and point-shaped pecking marks, in the lower zone still flaked, large flake on the side; underside shallowly hollowed out by flaking; Mayen lava. [Eifelmuseum Mayen, EM 2232]. (Hörter 1914: Pl. 13:7, fourth millstone from the right; Hörter 1994: fig. on p. 22).

45 - Meaux (département Seine-et-Marne, France), 23 Bd Jean Rose. Meta, "basalte ... du Massif Central ou du massif de l'Eifel”. (Lepareux-Couturier et al. 2011: 412, fig. 9 (date), fig. 27).

46 - Metz (département Moselle, France), Rue Paille-Maille, occupation layer sl744 (1st half of the 1st century CE). Catillus (fragment), diam. $39 \mathrm{~cm}$, h. at margin $8.8 \mathrm{~cm}$; eye not preserved; elbow-shaped perforation for the handle with oval mouth to the lateral surface (b. $5.8 \mathrm{~cm}$, h. $4.8 \mathrm{~cm}$, depth $6.4 \mathrm{~cm}$ ) and mouth to the top (diam.1.2 cm, depth $2.1 \mathrm{~cm}$ ); grinding surface partly secondarily trough-shaped and broken out; "basalte originaire des carrières de l’Eifel en Allemagne ou éventuellement de la chaîne des Puys du Massif Central ...”. (Asselin et al. 2017: 404, fig. 2:3)

47 - Monster, municipality of Westland (province of Zuid-Holland, Netherlands), "Het Geestje"; at the top of a dune with several foundations, at site III D. Fragment of a quernstone with biconcave cross section (type d), diam. $36 \mathrm{~cm}$, h. max. $10 \mathrm{~cm}$, “tephrite”. (van Heeringen 1992a: 10-11).

48 - Nenndorf, municipality of Holtriem (district of Wittmund, Germany), "Lange Äcker”, settlement 'Fst.Nr.2410/2:6', house site 1, pit 339. Fragment of catillus, 1.12 cm, b. 3.5$6.2 \mathrm{~cm}$, h. 2.8-8.8 cm, $1430 \mathrm{~g}$, "Basaltlava” with black inclusions. (Kreibig 2006: 99.164, pl. 23:339.8).

49 - Neuss (Rhein-Kreis Neuss, Germany); “found in Neuss”. Catillus, diam. 35,5 cm, “Basaltlava”. [Clemens Sels Museum Neuss, inv. no. R 1165e]. (Pause 2015: 158-159, fig. on p. 159).

50 - Niederzier-Hambach (district of Düren, Germany), fortified settlement. 1 Inner ditch (feature 176): Catillus (half), diam. 37.5 cm, "Basaltlava”. [RLMB 82.2081,04] (Joachim 2009, 51, pl. 20:11). - 2 Ditch 288: Catillus (fragment), diam. ?, "Basaltlava”. (Joachim 2009: 50, pl. 22:10)

51 - Nonnweiler-Otzenhausen (district of St. Wendel, Germany), hillfort "Hunnenring” on the Dollberg. Catillus (fragment), dimensions ?, “Basaltlava”. (Wiegert 2002: fig. 197).

52 - Noordbarge, municipality of Emmen (province of Drenthe, the Netherlands). 1 Catillus (fragment, less than half), diam. 36 cm; “basaltlava”. [Drents Museum, 1974 / VI 1019 + 1021] (Harsema 1979: 35, fig. 6:2). - 2 Catillus (fragment of the peripheral zone, $7 \mathrm{x}$ $31 \mathrm{~cm}$ ); diam $38 \mathrm{~cm}$; h. max. $9.5 \mathrm{~cm}$; h. min. $6.5 \mathrm{~cm}$; with elbow-shaped perforation for handle, "basaltlava". [Drents Museum, 1972 / XI 445]. (Harsema 1979: 35, fig 6:3; Hopman 2010: supplement 1, 1972-XI.445). 
53 - Oberusel-Oberstedten (Hochtaunuskreis, Germany), Heidetränk-Oppidum, “Goldgrube”. Catillus, diam. $40 \mathrm{~cm}$; “feinporiger Blasenbasalt, Blasengröße bis 0,2 cm”, presumed source of the raw material: “Mayen”. [Vortaunus Museum Oberursel, inv. no. 200/006] (Staubitz 2007: 64, pl. 1:1; Wefers 2012a: pl. 59:335).

54 - Oelde-Sünninghausen (district of Warendorf, Germany); farming community Wibberich, “Im Kampe”, "Heergaoren”, pit 104. Meta, diam. 36 cm; "Basaltlava”. (Wilhelmi 1973: 111, pl. 11:246).

55 - Oss (province of Noord-Brabant, the Netherlands), Brabantstraat, well S12.30. Catillus (fragment, about a quarter), diam. $37 \mathrm{~cm}$; h. at margin $10.5 \mathrm{~cm}$; h. at margin of eye 1.8 cm; “tefriet”, “uit de streek Mayen”. [V. 485.11] (Knippenberg 2011: 95.98, fig. 61: Hartoch et al. 2015: 178).

56 - Oss-Ussen (province of Noord-Brabant, the Netherlands), Vijver, pit P193 (Roman period). "One complete top stone with a socket for the spindle and a double-conical hole for the handle", "tephrite”. (Wesselingh 2000: 35, fig. 23).

57 - Oss-Ussen (province of Noord-Brabant, the Netherlands), Westerveld, from P271 (phase K). Meta; diam. $32 \mathrm{~cm}$; h. at margin $6 \mathrm{~cm}$; tephrite "from the quarries near Mayen in the Eifel”. (Schinkel 1998: 132, fig. 127b).

58 - Paddepoel, municipality of Groningen (province of Groningen, the Netherlands); terp Paddepoel II, excavation 1964. 1 Catillus (seven fragments, together nearly complete); diam. $37 \mathrm{~cm}$; h. at margin 9,6-10,4 cm; edge of eye broken away; around the peripheral drilling only minor traces of polishing due to weathering, "basaltlava". [find no. 152]. (Harsema 1967: 156 no. 4, fig. 8; Hopman 2010: supplement 1, 1968-X. 152 - 238128). - 2 Catillus (five fragments, together on third of the fringe; 31 x $12 \mathrm{~cm}$ ); diam. $35 \mathrm{~cm}$; h. at margin 9,7-10,6 cm; elbow shaped perforation with traces of polish, "basaltlava". [Find no. 152]. (Harsema 1967: 156 no. 4, fig. 8; Hopman 2010: supplement 1, 1968-X. 151 - 238128). 3

58a - Paddepoel, municipality of Groningen (province of Groningen, the Netherlands), Terp Paddepoel III (excavation 1964). 1 Meta (fragment, about a quarter), Dm. $\approx 34 \mathrm{~cm}$, h. at margin 2.6 - $4.3 \mathrm{~cm}$; domed grinding surface, smoothed by use; hole for spindle through; underside irregular concave; "basaltlava”. (Harsema 1967: 157, no. 8, fig. 9, 8; Hopman 2010: supplement 1, 1968-X. 208 - 238129). - 2 Meta (fragment, about one sixth of the edge area), diam. $32-34 \mathrm{~cm}$ (estimated); h. at margin $7.2 \mathrm{~cm}$; grinding surface convex, smoothed by use; underside irregular concave; "basaltlava". (Harsema 1967: 157, no. 9, fig. 9, 9, Hopman 2010: supplement 1, 1968-X. 172 - 238128).

59 - Pommern and Karden (district of Cochem-Zell, Germany), Martberg; pit 3000 (horizon Oberaden - Haltern). Catillus (half), diam. $38 \mathrm{~cm}$, h. at edge 11.4-11.9 cm; two horizontal holes for handles in the side face; two generations of secondary grooves on the grinding surface; eye with broken edge (irregular oval, 5.5 x $5.0 \mathrm{~cm}$, edge smoothed towards the centre of the quern); two additional holes (width $5.0 \mathrm{~cm}$ and $4.7 \mathrm{~cm}$, both rough at the edge) placed in the upper surface; "basalt"-like lava, coarse to fine pored, with quartz, augite and pyroxene. [GDKE Rheinland-Pfalz, Landesarchäologie Koblenz]. (Nickel 2011: 105.255, find no. 16.1300.3179.01, fig. 45)

60 - Rasquert (Raskwert), municipality of Baflo (province of Groningen, the Netherlands); in group of layers with pottery from the 1st century CE. Catillus (fragment, about one third, 34,5 x $17 \mathrm{~cm}$ ), diam. $36 \mathrm{~cm}$, h. at margin $10 \mathrm{~cm}$, "basaltlava". [Groninger Museum, inv. no. 1967/VI/1] (Harsema 1967, 145, fig. 5:3; van Heeringen 1985: 379, GR 1; Hopman 2010, supplement 1, 1967-V.20) 
61 - Roden, gem. Noordenveld (province of Drenthe, the Netherlands); found before 1900, 40 cm below the bog surface. Meta, diam. $37 \mathrm{~cm}$, h. $6 \mathrm{~cm}$, oval eye $(5 \times 3 \mathrm{~cm})$, “tefriet". [Drents Museum, no. 1900 / IV 4]. (Harsema 1979: 35; van Heeringen 1985: 379, DR 1; van der Sanden 1998, 116, no. 5).

62 - Rödgen, municipiality of Bad Nauheim (Wetteraukreis, Germany); augustan camp, pit in area 7. Catillus (fragment), diam. $\approx 32 \mathrm{~cm}$, h. at margin $\approx 8,4 \mathrm{~cm}$, "Mayener Basaltlava”. (Simon 1961, 59.63, fig. 2:40 a-b; pit: Schönberger 1961: fig. 3.8).

63 - Rossum, municipality of Maasdriel (province of Gelderland, the Netherlands); found in sand pit in the floodplain of the Waal. Catillus ("biconcave bovenligger"), diam. 34,5$36 \mathrm{~cm}$, "tefriet (bazaltlava)". It has a central perforation and two perforations on the side, of which one is broken. (van Heeringen 1985, 381, GLD 19; Hulst 1987: 213; Modderman \& Montforts 1991: 157, fig. 11:3).

64 - Saffig (district of Mayen-Koblenz; Germany), "Im Weidenfeld”. Meta, dimensions ?, "Basaltlava”. [Pellenz Museum, Nickenich; currently in depot] (Hörter 2000, fig. 2:5; Schäfer 2000: Pl. 33 centre; site: Oesterwind \& Schäfer 1985: Pl. 1; information from Klaus Schäfer via Email of Bernd Oesterwind, 5.4.2017).

65 - Saverne (département Bas-Rhin, France), oppidum "Fosse des Pandours", pit no. 3. Two pairs of quernstones (one of Brillerij type) with diam. between 36 and $39 \mathrm{~cm}$, "basalte". (Jodry \& Féliu 2009: 70, fig. 5; Bonaventure 2010, vol. 2, 471-475 Bbk 9 Puits 3).

66 - Starý Kolín (district Kolín, Czech Republic). Catillus, diam. 37,5-38,5 cm; grinding surface round, concave, picking marks are lightly grinded; eye slightly oval (diam. 5,2 x $5,7 \mathrm{~cm}$ ); top face round concave with picking marks; lateral face straight, comprising a hole for the handle (depth 5,1 cm, diam. 3,2 cm); probably Ettringen lava (Bellerberg volcano near Mayen). [museum Kolín; inv. no. 450] (Wefers \& Gluhak 2010: 4, fig. 1)

67 - Tongeren (province of Limburg, Belgium); Bilzersteenweg, Rijksnormaalschool; with Roman finds. Catillus; diam. $37 \mathrm{~cm}$; h. at margin: 7.5 - $5.2 \mathrm{~cm}$; eye round (diam. 4.9 $\mathrm{cm}$ ); inclination of grinding surface: 3; elbow-shaped perforation for handle, on the lateral face aperture rectangular, abraded at the lower edge $(3.5 \times 2.2 \mathrm{~cm})$, on the top face aperture rectangular to elliptical $(5.2 \times 7.9 \mathrm{~cm})$; top face and lateral face with picking marks; underside smoothed; weight: $10.5 \mathrm{~kg}$; “foidite téphritique / phonotéphrite”, source: “Bellerberg, Kottenheimer Winfeld, Eifel”. [Gallo-Romeins Museum Tongeren; Inv. GRM 4473] (Hartoch et al. 2015: 178-182 no. 18, fig. 121).

68 - Utrecht (province of Utrecht, the Netherlands); Sportpark Terweide, settlement area LR42 (20 - 60 CE). 1 Catillus (fragment) with elbow-shaped perforation for handle; “tefriet”. 2 Meta (about half); diam. 31 cm; “tefriet”. (Mooren 2009: 124, fig. 6.254, 6.255; Taayke et al. 2012: 210 note 369).

69 - Valthermond, municipality of Borger-Odoorn (province of Drenthe, the Netherlands), probably found at or below fenland trail Valtherbrug. Catillus, diam. $34 \mathrm{~cm}$, h. at margin 8 cm, "tefriet”. [Drents museum, 1879/IV 6] (van der Sanden 1998: 115, fig. 6; Hopman 2010: supplement 1, 1879-IV.6).

70 - Warstiens, Leeuwarden municipality (province of Friesland, the Netherlands), west of the bridge over the Langdeel. Catillus (fragment, about a quarter; 26,5 x 15,5 cm); diam. 30 cm; h. at margin 7,5 cm; "basalt"-like lava according to photo. (Hopman 2010: supplement 1, Doos 4841 [FM 1968-IX-26]).

71 - Wederath, municipality of Morbach (Belginum) (district Bernkastel-Wittlich, Germany), "Hochgerichtsheide"; grave 1814. Meta (two fragments), "Basaltlava”. [RLM Trier, Inv.-Nr. 80,356a-c]. (Cordie-Hackenberg \& Haffner 1991: 119, pl. 472 grave 1814 c).

72 - Winsum (province of Groningen; the Netherlands), terp Schelum. Catillus (fragment, about a quart, 23,5 x $14 \mathrm{~cm}$ ); diam. $35 \mathrm{~cm}$; h. at margin $10 \mathrm{~cm}$; "basalt"-like lava according to photo. (Hopman 2010: supplement 1, Doos 4841 (FM 1977-V-25)). 
73 - Wölferlingen (Westerwaldkreis, Germany); found 1981 excavating an building pit at the southern outskirts of the village. Catillus, fragment (34,2 x 19,1 cm), original diam. 42,0 cm; h. at margin 12,4 - 13,1 cm, eye round (diam. 4,8 cm); "phonolitischer Tephrit (Gruppe 1)”. (Wefers 2012a: pl. 108:576).

74 - Xanten-Birten (district of Wesel, Germany), legionary camp Vetera I, in trench 39 outside the Neronian facillity (pit, surface). Catillus (fragment), diam. 44 cm, h. $3-8,5$ cm; “Basaltlava”. [RLMB, inv. no. 80,356a-c]. (Hanel 1995: 73.758, no. I 19, pl. 164:I 19).

75 - Zeijen-Witteveen (Zeyen), municipality of Tynarloo (province of Drenthe, the Netherlands), Zeijen-II enclosure. Several fragments of upper stones of Brillerij type, “Tephrit”. (Harsema 1979: 35; van Heeringen 1985: 379 DR 4; site: Waterbolk 1977; de Vries 2015: 39). 